九州大学学術情報リポジトリ

Kyushu University Institutional Repository

Functional Evoltion of 0toscaphites puerculus (JIMBO) and Scaphites planus (YABE), Upper Cretaceous Ammonites

Tanabe, Kazushige

Faculty of Science, Kyushu University

https://doi.org/10.5109/1544179

出版情報：九州大學理學部紀要：Series D, Geology. 23 (3)，pp.367-407，1977-02-25. Faculty of Science, Kyushu University バージョン：

権利関係 : 
Mem. Fac. Sci., Kyushu Univ., Ser. D. Geol., Vol. XXIII, No. 3, pp. 367-407, text-figs. 1-18, tables 1-5, pls. 62-64, Feburary 25, 1977

\title{
Functional Evolution of Otoscaphites puerculus (JIMBO) and Scaphites planus (YABE), Upper Cretaceous Ammonites
}

\author{
Kazushige TANABE
}

\begin{abstract}
Otoscaphites puerculus (Jimbo) and Scaphites planus (YABE) occur abundantly in the Turonian of Hokkaido and south Sakhalin. The two species are nearly satisfied with an indispensable condition of the fossil population concept by reason of the characteristic in the mode of occurrence. Biometric and hydrostatic examinations on 42 samples for the two species from Naibuchi, Saku, Obira and Oyubari areas, have been made to obtain the quantitative data on their functional evolution. The analyses of individual relative growth of radius length to total rotation angle, septal and ventral wall thickness to radius length and variation of phragmocone size of adult shells indicate that the two species evolved in parallel in the direction of a buoyancy excess. Approximate calculation of the buoyancy of several well-preserved adult shells suggests that the two species changed with time in the mode of life of adult stage from benthic to planktic. The suture complexity of the two species increases with time in inverse proportion to the growth of septal and ventral wall thickness. Their inhabitable depth range may be shallower than that of modern Nautilus, because of their smaller value of the relative siphuncular strength than in Nautilus. Judging from the coexistent and sympatric mode of occurrences, similarity of ontogeny until 8 or $9 \pi$ stage and parallel historical change of certain shell characters, it may be possible that the relationship between the two nominal species is a sexual dimorphism.
\end{abstract}

\section{Introduction}

Functional morphology is one of the most important field of paleontology. The main purpose of functional morphology is to realize the meaning of morphology of organisms as a first step of taxonomy, paleoecology and evolution. There are a number of factors such as historical, functional, structural and chance factors which may control the morphology of organisms (SEILACHER, 1970; RAUP, 1972). Throughout the solution of these factors, we shall be able to estimate the biological meaning of morphology sufficiently.

Ammonoids have aroused interest of many paleontologists because of their remarkable evolution, diverse shell morphology and complicated organization; hence a number of functional morphologic works have been done from various viewpoints. However, most of previous works were treated above the species level, and intraspecific evolution and its functional significance have not yet 
been clarified to our satisfaction.

Recent works on some living cephalopods by DENTON and GILPIN-Brown (1961a, b, 1966, 1971, 1973), Denton, Gilpin-Brown and Howarth (1967), BidDer (1962), Collins and Minton (1967) and HAven (1972), have given a lot of important information on the floatation mechanism and paleoecology of extinct cephalopods including ammonoids.

The Upper Cretaceous scaphitid ammonites may be suitable material for the study of functional evolution, because of their fine evolutionary development and their cluster occurrences (CoBBAN, 1951; WIEDMANN, 1965, 1969). In this study, I examine the mode of occurrence, relative growth and variation of the two Turonian species, Otoscaphites puerculus (JIMBo) and Scaphites planus (YABE), discussing their intraspecific evolution from the standpoint of functional morphology. I also discuss the taxonomic relationship between the two species with special reference to the possibility of sexual dimorphism.

Acknowledgements.-This study has been undertaken under the supervision of Professor Tatsuro Matsumoto of Kyushu University, to whom I express my sincere gratitude.

I am indebted to Associate Professor Itaru HAYAMI of the University of Tokyo, Professor Tsugio SHuto of Kyushu University and Dr. William J. KeNNEDY of Oxford University for their careful review of the manuscript.

Thanks are extended to Professor Gerd G. Westermann (McMaster University), Associate Professor Kametoshi Kanmera and Dr Hiromichi Hirano (Kyushu University), Dr. Tomowo Ozawa (University of Tokyo), Dr. Ikuwo OBata (National Science Museum) for their instructive suggestions about my research, to Professor Tetsuro HaNaI (University of Tokyo), Dr. Yasumitsu KANIE (Yokosuka City Museum) and Mr. Makoto OKAMURA (Tohoku University), who have given me a permission to examine the Type Collections in their care. Miss Mutsuko HAYASHIDA of Kyushu University kindly assisted me in preparing the typescript.

This study was financially supported by the Matsunaga Science Foundation, Tokyo, the Japan Education Association and the Fund of scholarship of Professor MATSUMOTO.

\section{Material}

In this study I examined 556 specimens belonging to 42 samples of $O$. puerculus and 507 specimens belonging to 42 samples of $S$. planus. These samples were collected from the Naibuchi area of south Sakhalin, and the Saku, Obira (=Tappu) and Oyubari areas of Hokkaido, as indicated in Fig. 1.

Each sample is composed of several specimens. These specimens were separated from a single calcareous nodule with aid of an air scriber machine. The stratigraphic position of each sample is estimated by the thickness, measured from the initial horizon of the earliest appearance of the two species.

As shown in Fig. 2, every sample for the two species was obtained from Inoceramus labiatus to $I$. teshioensis Zones in the areas studied. The two species 


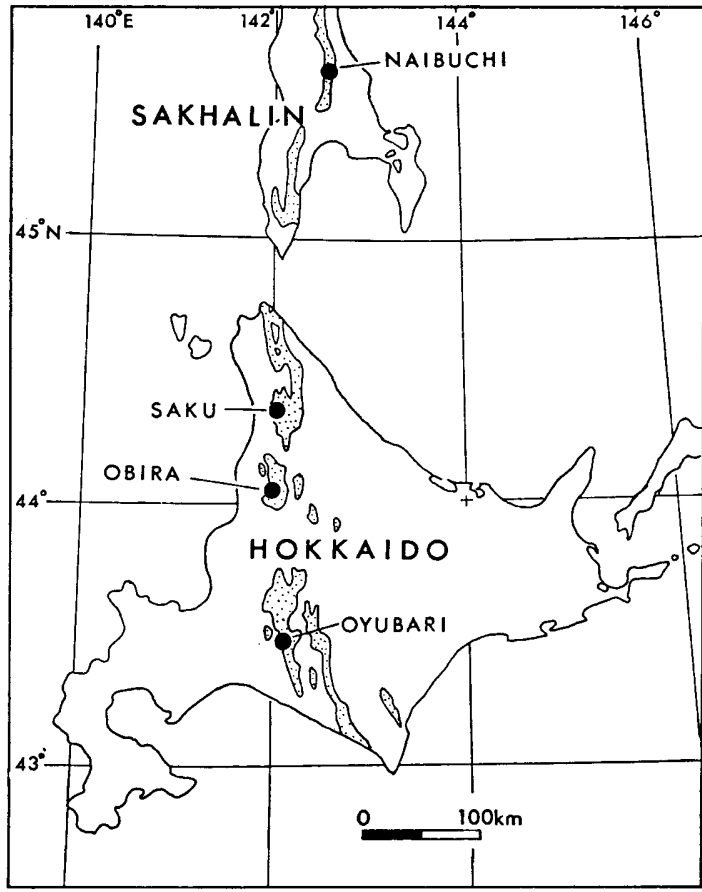

Fig. 1. Index map showing the outcrop of the post-Aptian deposits and the sampling areas of $O$. puerculus and $S$. planus in the central zone of Hokkaido and south Sakahlin.

occur especially abundantly in the lower part of the $I$. hobetsensis Zone of the Obira and Oyubari areas. According to MAtsumoto $(1959 \mathrm{a}, 1967)$ and MATSUмото et al. (1977), the above-mentioned Inoceramus are important zonal indices of the Turonian in Japan and its adjacent areas. Moreover, such international Turonian subzonal indices as Vascoceras, Fagesia, Mammites, Pseudaspidoceras, Collignoniceras and Subprionocyclus were collected from the same beds as the present two species in the Obira and Oyubari areas (Matsumoto et al., 1977; Hirano et al., 1977; TANABE et al., 1977). These lines of evidence indicate that the present two species range from Lower to Upper Turonian.

Every sample, except for the Naibuchi samples, is stored in the Type Collection of Kyushu University. Among the samples examined, only the illustrated specimens are designated by a registered number with prefix, GK. H.

3 samples of the two species from the Naibuchi area are stored in the Type Collection of the University Museum of the University of Tokyo with registered number beggining with prefix, MM.

\section{Naibuchi samples}

3 samples of the two species, namely $\mathrm{N} 315 \mathrm{~d}, \mathrm{~N} 317 \mathrm{~d}$ and $\mathrm{N} 320$, were used for this study. They were collected by T. MATsumoto from the middle course of the Naibuchi Valley in 1937. The detailed fossil localities are summarized in Matsumoto (1942, pl. 8). The horizons of these samples correspond to MATSUMoto's Mh-1 through Mh-2 and are included in $I$. hobetsensis Zone of 


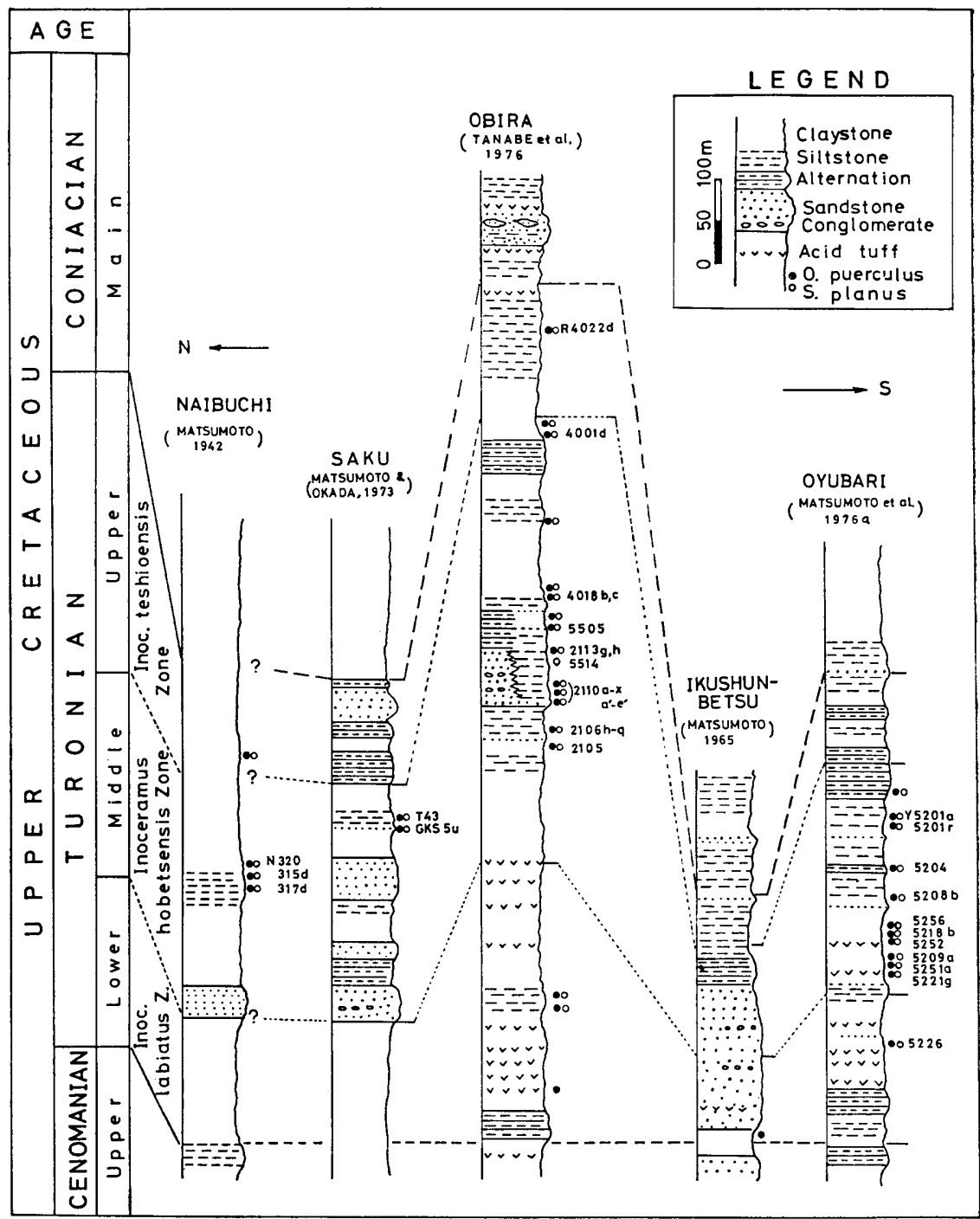

Fig. 2. Stratigraphic columnar sections of the Turonian sequences in the selected areas af Hokkaido and south Sakhalin. Stratigraphic distribution of $O$. puerculus and $S$. planus, and horizons of examined samples are indicated. (MATSUmoto et al. 1976a) and (TANABE et al. 1976) should be ammended to (HIRANo et al. 1977) and (TANABE et al. 1977) respectively.

Middle Turonian.

\section{Saku samples}

Both species occur abundantly in the Saku formation of the upper part of the Middle Yezo Group, typically exposed along the Saku-gakkonosawa River. In this study I examined 4 samples, namely $\mathrm{T} 43, \mathrm{~T} 1083 \mathrm{p}$, T $1079 \mathrm{p}$ and GKS $5 \mathrm{u}$. The former 3 samples were collected by T. MATSUMoto in 1938 and 1960, and the latter one by M. OKAMURA in 1974. 
The fossil localities of the former 3 samples are shown in Matsumoto (1942, pl. 12) and MATSUmoto and OKADA (1973, fig. 3). The locality of GKS $5 \mathrm{u}$ is in accord with T 5054 by Matsumoto and OKADA. The above-mentioned samples were collected from MATSUMoTo's member IId (I. hobetsensis Zone).

Unfortunately, the centre of the phragmocone is deformed or destroyed in almost every specimen; accordingly, I merely examined these samples for the analysis of mode of occurrence.

\section{Obira samples}

The Turonian sequence in this area is widely distributed along the upper course of the Obirashibe Valley and its tributaries. The geological structure in this area is rather simple, except for the southwestern part along the Nakakinembetsu River. Numerous well-preserved marine megafossils are contained in calcareous nodules from the Turonian claystone to fine sandy siltstone.

Both species occur abundantly throughout the Turonian sequence in this area. Particularily in the lower part of the Middle Turonian, they occur in clusters, with other heteromorphs such as Nipponites, Scalarites, Hyphantoceras, Madagascarites, Eubostrychoceras and other species of Scaphites. On the whole, the biofacies in this part can be called the Scaphites facies, as pointed out by MATSUMoTo and OKADA (1973).

I examined 26 samples from this area. These samples were collected by T. Matsumoto, T. Muramoto, H. OKada, H. Hirano, Y. Miyata and me in 1971-1974. The sample localities and their stratigraphic positions are summarized in TANABE et al. (1977, figs. 6, 8-10; table 2).

\section{Oyubari samples}

Turonian strata in this area are well exposed along the upper course of the Yubari River, and its tributaries. They consist mainly of claystone to fine sandy siltstone, sometimes with thin layers and laminae of fine sandstone. Occurrences of scaphitid ammonites are fairly frequent throughout the Turonian. However, owing to the complicated geologic structure and the lack of key beds, it is difficult to decide the precise stratigraphic positions of the fossil localities, which are scattered in a wide area.

I examined 9 samples from the lower course of the Hakkinzawa (=Shirakinzawa) River. They were collected by T. Matsumoto, H. Hirano and me in 1973-74. I have already shown the localities of several samples of O. puerculus (TANABE, 1975, text-fig. 4). HIRANo et al. (1977) recently summarized the Mid-Cretaceous stratigraphy in this area. The sample localities and their stratigraphic position are indicated in that paper. Biostratigraphically, the samples examined were obtained from the upper part of the I. labiatus Zone to the lower part of 1 . hobetsensis Zone.

\section{Mode of occurrence}

The occurrence of present $O$. puerculus and $S$. planus in the Turonian of Hokkaido and south Sakhalin is more conspicuous in the western belt than in the eastern belt. However, the areas of abundance are scattered in the western 
belt. As already shown in Fig. 2, the stratigraphic and geographic distribution of the two species are quite in accord with each other. Furthermore, they occur together in almost every fossil locality.

In order to determine the mode of occurrence of the two species quantitatively, I examined the numerical ratio of $O$. puerculus to $S$. planus. The result is summarized in Fig. 3. The chi-square tests for the numerical ratio in each locality indicate that all the samples, except for $T 43$ and $R 5505$, do not show a significant difference in the number of specimens with $95 \%$ confidence. This evidence implies that the two species occur at a ratio of $1: 1$ almost in every nodule.

However, the ratio of the number of adult shells to the total number differs between the two species. In the case of $O$. puerculus, the ratio is more than $50 \%$ in every case, as against less than $20 \%$ in most sample of S. planus.

MAKowsKI (1962) mentioned that the state of preservation and numerical ratio of ammonoid specimens are apt to be greatly influenced by their absolute size.

In the case of the present two species, the shell size of adult specimens of $S$. planus is much larger than that of O. puerculus. Accordingly, the difference of the ratio of the number of adult specimens between the two species may probably resulted from the difference of shell size.

The present two species form a majority of the megafossils from the lower Middle Turonian in the areas studied. However, from the upper Middle Turonian to the Upper Turonian their occurrence is not so conspicuous as that from the lower Middle Turonian. Other Scaphites such as S. yokoyamai, S. yonekurai and $S$. aff. subdelicatus are poorer in occurrence as compared with the present two species (TANABE, 1977).

In the adult specimens, the body chamber is commonly in a good state of preservation as well as the phragmocone. In the case of $O$. puerculus, a pair of long lateral lappets are also preserved at a high rate in the adult specimens. For examples, the rates are $73 \%$ for $\mathrm{R} 2110 \mathrm{a}, 79 \%$ for $\mathrm{R} 2110 \mathrm{c}$ and $100 \%$ for $\mathrm{R} 2110 \mathrm{x}$. If we take into account destruction during cleaning, the rate must be close to $100 \%$ in almost every sample.

On the contrary, in young shells of the present two species, the body chamber is often secondarily deformed or damaged, as with those of other normally coiled ammonites.

It is absolutely necessary for the study of population paleontology to decide whether the sample studied is autochthnous or allochthonous, for an autochthonous sample is an indispensable condition for recognition of fossil population which will reflect the interbreeding natural population (MAYR, 1970).

As compared with such benthic animals as bivalves, gastropods and brachiopods, nektic or planktic animals are probably apt to loose their original population properties as fossil assemblages, owing to their varied habitats and mobility in life. In the case of ammonoids, at least a part of them may had a nektic or planktic mode of life (HEPTONSTALL, 1970; RAUP, 1973).

The main factor in the post-mortem transportation of ammonoid shells may 

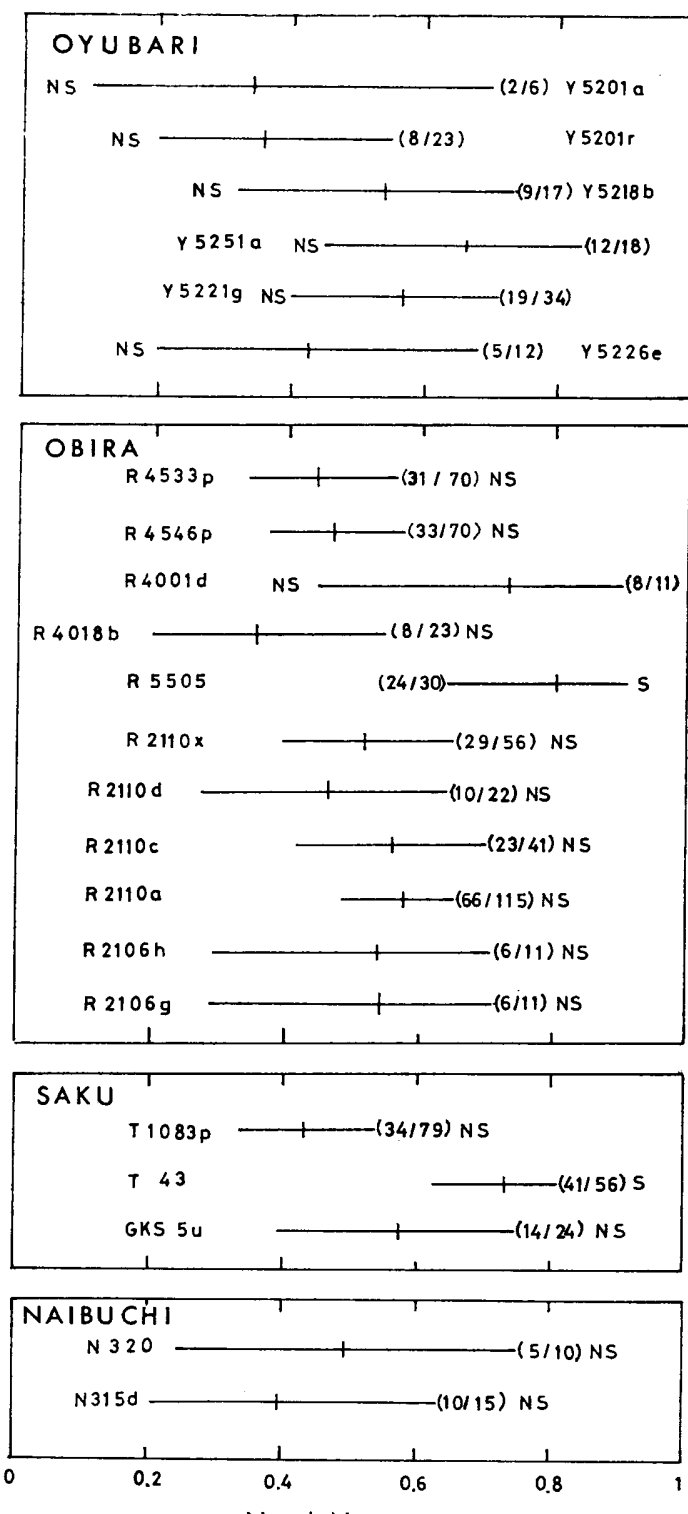

$\mathrm{N}_{\mathrm{O}_{p}} / \mathrm{N}_{\mathrm{O}_{p}}+\mathrm{s}_{\mathrm{p}}$

Fig. 3. Numerical ratio of the number of specimens of $O$. puerculus to that of $O$. puerculus plus $S$. planus in a pair of sympatric samples. The mean value (cross line) and its $95 \%$ confidence interval (horizontal line) are shown for each sample. The original ratio is shown in parentheses. The alphabets indicate the results of the chi-square tests. S: significant with $95 \%$ confidence, NS: not significant with 95\% confidence. 
be a nekroplanktic drift. With respect to the nekroplanktic drift of ammonoid shells, we should consider the possibility from such indirect evidence as buoyancy calculations, floating experiments using exact models, and their mode of occurrence.

The data of post-mortem drift of living Nautilus shell give us a reliable information on this point. HAMADA $(1964,1965)$ and TORIYAMA et al. (1965) considered the post-mortem drift and the grade of breakage of $N$. pompilius (LINNÉ) from the standpoint of paleofluminology. According to these works postmortem shells are distributed in the area that encircles the habitat, and sometimes they are transported for a long distance, riding on ocean currents. Moreover, HAMADA (1965) mentioned that the grade of breakage and the frequency of attachment of epifauna are related to the distance and the time of drift.

Judging from the above-mentioned evidence on mode of occurrence, postmortem drift is actually negligible for the adult shells of the present two species.

Furthermore, the young shells of the two species always accompany adult shells; accordingly long distance drift or transportation of the young shells may not to be supposed.

Consequently, I believe that the present material is virtually autochthonous, and satisfy this indispensable condition of the fossil population concept.

\section{Biometric Analysis}

During the ontogenetic development, the present two species change their shell morphology from normal to abnormal coiling, although their coiling pattern both reflect planispiral growth.

For the biometric analysis of each specimen I prepared a polished median dorso-ventral section, cut in parallel with the base of body chamber.

Protoconch and nepionic sizes, phragmocone diameter of adult shell, radius length $(R)$ and spiral length of phragmocone, length of ventral wall of phragmocone and body chamber, number of septa, thickness of ventral wall ( $\mathrm{T}$ ) and that of septum (S) were measured on the median section. Among these characters, $\mathrm{R}, \mathrm{T}$ and $\mathrm{S}$ were measured at intervals of $0.5 \pi$.

Radius length, shell diameter (D), umbilical diameter (U) and its half length (C), whorl breadth (B) and height (H), siphuncular diameter (Sd), thickness of siphuncular wall $(\mathrm{Tw})$ and that of ventral wall were measured along the cross section at intervals of $1 \pi$. The basic morphology, orientation, measurements and parameters are diagrammatically shown in Fig. 4.

Each character was measured with a micrometer of accuracy, $1 \mu$ (Nipponkogaku Co.), attached to a binocular microscope (Olympus Co.) with magnification of 40 and 100 times. The results of measurements were checked again making use of a profile projector (Nipponkogaku Co.) of accuracy, $1 \mu$, with a digital printer. I also used a WILD microscope for sketching the magnified outline (magnification $\times 25,50$ ) of median section and suture. The outline of the section and suture were traced by a curvometer with accuracy of $0.5 \mathrm{~cm}$. The 

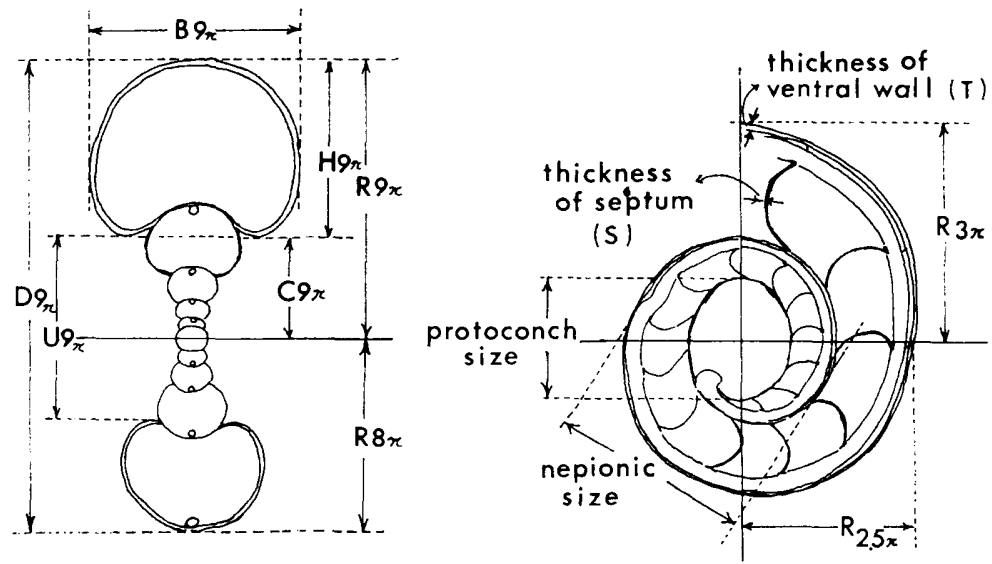

$$
S=\frac{B n}{H n} \quad \text { W. R. }=\left(\frac{R n}{R n-1}\right)^{2} \quad \text { D. G. }=\frac{C n}{R n}
$$

Fig. 4. Basic morphology, orientation, measurements and parameters in the median and cross sections of $O$. puerculus and $S$. planus.

measured value of each character is the average of two measurements. To estimate the approximate buoyancy of the adult shells, I used an automatic balance of accuracy, $1 \mathrm{mg}$. The method of volumometry was mentioned in my previous study (TANABE, 1975).

The following abbreviations were used for the biometric description.

$\mathrm{N}$ : number of specimens in a sample, O.R.: observed range, $\overline{\mathrm{X}}$ : arithmetic mean, V: coefficient of variation, $\mathrm{s}$ : standard deviation, $\sigma \overline{\mathrm{x}}$ : standard error of the mean, $\mathrm{P}:$ probability level, $\nu$ : degrees of freedom, $\overline{\mathrm{X}} \pm \mathrm{t}_{0.05} \sigma \overline{\mathrm{x}}: 95 \%$ confidence interval of the mean, $\alpha$ : growth ratio, $\sigma \bar{\alpha}$ : standard error of the mean of the growth ratio, $\beta$ : initial growth index, $\mathrm{r}$ : correlation coefficient, C. D.: coefficient of difference.

\section{A. Individual relative growth}

Growth of radius length-MOSELEY (1838), THOMPSON (1917) and HUXLEY (1932) had already mentioned that the growth of cephalopod shell whorls is given by the following expression.

$$
\mathrm{R}=\mathrm{e}^{\theta \cot \omega},
$$

where $R$ is the radius length of the shell, $\theta$ is the total rotation angle and $\omega$ is the spiral angle (the angle between the tangent of the curve and the radius length of the curve).

WADDINGTON (1927), HAARLÄNDER (1952) and OBATA (1959, 1960) realized that the growth of the radius length of many ammonoid shells can be expressed by the above-mentioned expression with high degrees of correlation. 
Table 1. Student's $t$-tests (right upper) and the coefficient of difference (left between a pair of samples of $O$. puerculus and $S$. planus from the Otoscaphites puerculus (JIMBO)

2nd growth-phase $(2-3.5 \pi)$

\begin{tabular}{|c|c|c|c|c|c|}
\hline & R 2110a & $\mathrm{R} 2110 \mathrm{c}$ & $R 2110 x$ & R 5505 & R 4001d \\
\hline R 2110a & & -0.41 & -0.10 & 1.61 & -1.33 \\
\hline R $2110 c$ & 0.071 & & $0.31^{*}$ & $1.37 *$ & -0.71 \\
\hline$R 2110 x$ & 0.061 & 0.068 & & $1.40^{*}$ & -1.52 \\
\hline R 5505 & 0.277 & 0.313 & 0.330 & & -1.97 \\
\hline $\mathrm{R} 4001 \mathrm{~d}$ & 0.282 & 0.179 & 0.317 & 0.518 & \\
\hline
\end{tabular}

3rd growth-phase $(4-5.5 \pi)$

\begin{tabular}{l|ccccc} 
& $\mathrm{R} \mathrm{2110 \textrm {a }}$ & $\mathrm{R} \mathrm{2110c}$ & $\mathrm{R} \mathrm{2110x}$ & $\mathrm{R} 5505$ & $\mathrm{R} 4001 \mathrm{~d}$ \\
\hline $\mathrm{R} 2110 \mathrm{a}$ & 1.91 & $-0.65^{*}$ & 1.25 & -1.02 \\
$\mathrm{R} 2110 \mathrm{c}$ & 0.368 & $\underline{2.95}$ & -0.30 & -2.32 \\
R 2110x & 0.224 & 0.564 & & $1.47^{*}$ & $-0.60^{*}$ \\
R 5505 & 0.224 & 0.070 & 0.347 & & -1.49 \\
R 4001d & 0.237 & 0.578 & 0.163 & 0.400 & \\
\hline
\end{tabular}

4th growth-phase $(5.5 \pi-)$

\begin{tabular}{|c|c|c|c|c|c|}
\hline & $\mathrm{R} 2110 \mathrm{a}$ & $\mathrm{R} 2110 \mathrm{c}$ & $\mathrm{R} 2110 \mathrm{x}$ & R 5505 & R 4001d \\
\hline $\mathrm{R} 2110 \mathrm{a}$ & & 0.26 & -0.20 & -1.58 & -3.48 \\
\hline $\mathrm{R} 2110 \mathrm{c}$ & 0.049 & & -0.47 & -1.80 & $-\overline{3.65}$ \\
\hline$R 2110 x$ & 0.031 & 0.091 & & -1.73 & -3.92 \\
\hline R 5505 & 0.370 & 0.407 & 0.391 & & $-\overline{1.51}$ \\
\hline R 4001d & 0.762 & 0.891 & 0.840 & 0.418 & \\
\hline
\end{tabular}

* AspiN-Welch's method, underline: $\mathrm{P}<0.01$, dashed underline: $0.05>\mathrm{P}>0.01$.

We can express the growth of radius length of the shell to the total rotation angle by using the least square method. The equation is given by the alteration of the above-mentioned equation.

$$
\mathrm{R}=(\log \mathrm{c}) \cdot \theta^{\alpha},
$$

where $\log \mathrm{c}$ is the initial growth index $(\beta)$.

I have already demonstrated that the growth of radius length in $O$. puerculus shows the existence of 4 growth phases, namely the 1 st $(0-1.5 \pi)$, the 2nd $(2-3.5 \pi)$, the 3 rd $(4-5.5 \pi)$ and the 4 th $(5.5 \pi-)$ phases during the ontogenetic development (TANABE, 1975). The same mode of growth of radius length is observed in S. planus.

The growth pattern of the two species shows the existence of pronounced breaks in growth between the 1st and the 2nd phases and also between the 2nd and the 3rd phases in every specimen. These breaks may originate in the nepionic constriction existing at about $1.3 \pi$ stage.

To determine the ontogenetic change of the growth ratio quantitatively, 
lower) for the mean of growth ratio of radius length to total rotation angle Obira area.

Scaphites planus (YABE)

2nd growth-phase $(2-3.5 \pi)$

\begin{tabular}{l|ccccc} 
& $\mathrm{R} \mathrm{2110 \textrm {a }}$ & $\mathrm{R} \mathrm{2110 \textrm {c }}$ & $\mathrm{R} \mathrm{2110 \textrm {x }}$ & $\mathrm{R} \mathrm{4018b}$ & $\mathrm{R} \mathrm{4022 \textrm {d }}$ \\
\hline R 2110a & & 1.03 & -1.26 & 2.00 & -0.30 \\
R 2110c & 0.223 & & -1.75 & 0.41 & -0.49 \\
R 2110x & 0.209 & 0.356 & & 2.27 & 0.13 \\
R 4018b & 0.424 & 0.113 & -0.558 & - & -0.93 \\
R 4022d & - & - & - & - & \\
\hline
\end{tabular}

3rd growth-phase $(4-5.5 \pi)$

\begin{tabular}{l|ccccc} 
& $\mathrm{R} \mathrm{2110 \textrm {a }}$ & $\mathrm{R} \mathrm{2110 \textrm {c }}$ & $\mathrm{R} \mathrm{2110 \textrm {x }}$ & $\mathrm{R} 4018 \mathrm{~b}$ & $\mathrm{R} \mathrm{4022d}$ \\
\hline $\mathrm{N} 2110 \mathrm{a}$ & & 0.81 & -1.41 & $\underline{3.01}$ & -1.42 \\
$\mathrm{R} 2110 \mathrm{c}$ & 0.153 & & -1.79 & 1.82 & -1.39 \\
$\mathrm{R} 2110 \mathrm{x}$ & 0.243 & 0.367 & & $\underline{3.67}$ & -0.85 \\
$\mathrm{R} 4018 \mathrm{~b}$ & 0.784 & 0.536 & 0.101 & - & -3.04 \\
$\mathrm{R} 4022 \mathrm{~d}$ & - & - & - & - & \\
\hline
\end{tabular}

4th growth-phase $(5.5 \pi-)$

\begin{tabular}{l|ccccc} 
& $\mathrm{R} \mathrm{2110 \textrm {a }}$ & $\mathrm{R} \mathrm{2110 \textrm {c }}$ & $\mathrm{R} \mathrm{2110 \textrm {x }}$ & $\mathrm{R} \mathrm{4018b}$ & $\mathrm{R} \mathrm{4022 \textrm {d }}$ \\
\hline $\mathrm{R} 2110 \mathrm{a}$ & & -0.66 & -1.25 & -3.61 & -2.58 \\
$\mathrm{R} 2110 \mathrm{c}$ & 0.131 & & -0.44 & -2.86 & -2.25 \\
$\mathrm{R} 2110 \mathrm{x}$ & 0.223 & 0.091 & & -2.58 & -2.15 \\
$\mathrm{R} \mathrm{4018b}$ & 0.963 & 0.799 & 0.698 & - & -1.52 \\
$\mathrm{R} 4022 \mathrm{~d}$ & - & - & - & - & - \\
\hline
\end{tabular}

I performed $t$-tests phase by phase for a pair of samples from the Obira area after having finished the chi-square tests and F-tests. The results are summarized in Table 1. With respect to the 2nd phase, the growth ratios of the two species are generally constant with time. In contrast with the 2 nd phase, the growth ratios at the 3 rd and the 4 th phases of the two species are gradually increased with time.

MAYR et al. (1953) proposed the expedient method for the comparison of two local populations by using coefficient of difference (C.D. $=\overline{\mathrm{X}}_{1}-\overline{\mathrm{X}}_{2} / \mathrm{s}_{1}+\mathrm{s}_{2}, \because$ $\overline{\mathrm{X}}_{1}>\overline{\mathrm{X}}_{2}$ ). According to them, the expedient limit of the significant difference at the subspecific level is given by C.D. $=1.28$ (degree of non-overlap of two local population curves is $90 \%$ ). Using this method, I examined C.D. phase by phase on each sample of the two species. The results that are appended in Table 1, indicate that a significant difference above the subspecific level is not observed for any pair of samples.

The changes of the growth ratio at the 3rd and the 4th phases of the two species are summarized in Fig. 5. As is obvious in this figure, the growth 

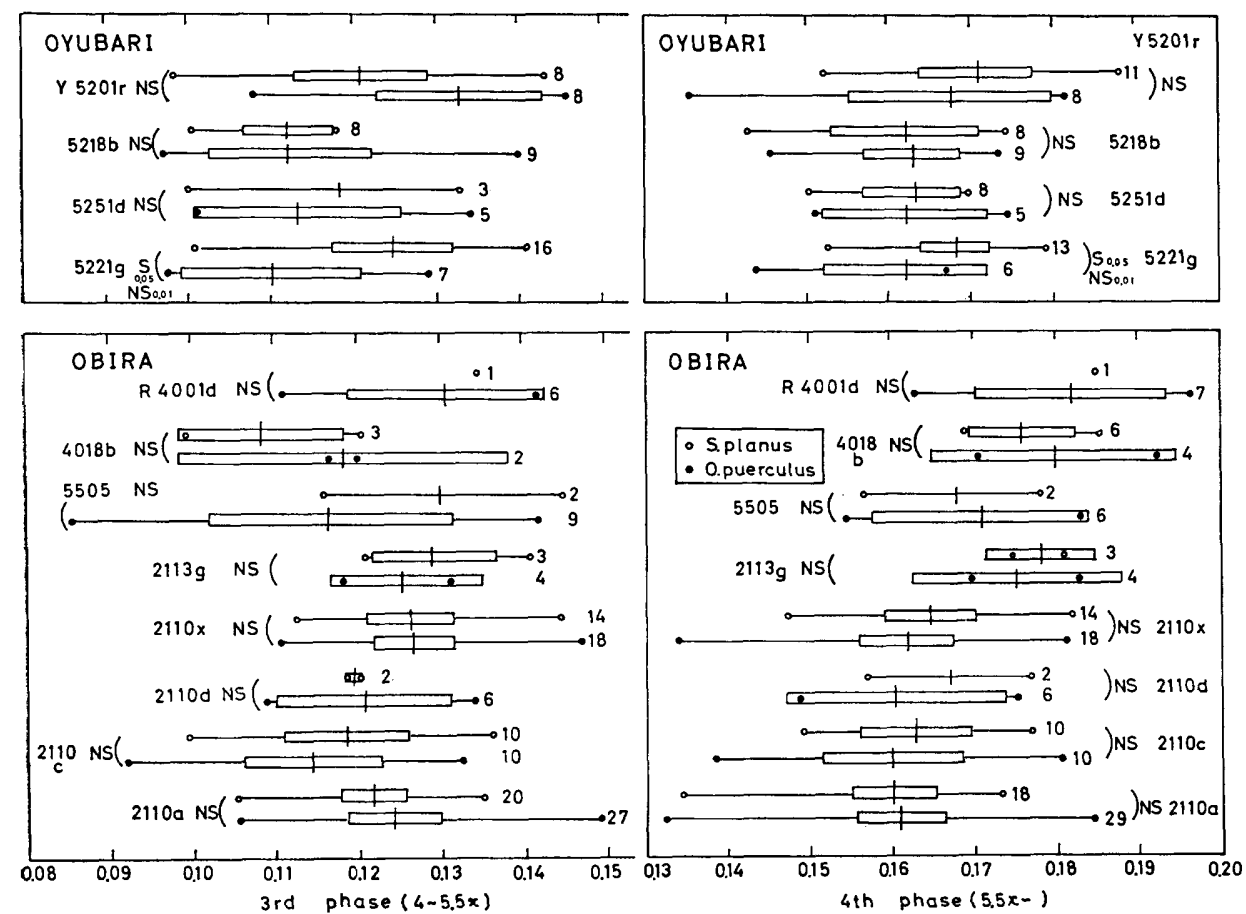

Growth ratio of radius length to total rotation angle

Fig. 5. Historical changes in growth ratio of radius length to total rotation angle in the 3rd and 4th growth-phases of $O$. puerculus and $S$. planus in the sequence of the Obira and Oyubari areas. The sample mean (cross line) and its $95 \%$ confidence interval (white rectangles) and the observed range (harizontal line) are shown for each sample. The number beside each horizontal line indicates the sample size. The results of $t$-tests between a pair of samples of the two species from the same localities are also shown in this figure. $\mathrm{S}_{0.05}$ : sighificant with $95 \%$ confidence, $\mathrm{NS}_{0.01}$ : not significant with $99 \%$ confidence, NS : not significant with 95 and $99 \%$ confidence.

ratios at each phase for the two species are very similar to each other, and $t$-tests indicate that no significant difference exists between a pair of samples from the same localities with $95 \%$ or $99 \%$ confidence.

Consequently, it may be concluded that the present two species have the same evolutionary tendency for the growth of radius length.

Growth of whorl height, breadth and umbilical diameter-Growth of whorl height, breadth and umbilical diameter express the fundamental morphology of ammonoid shells. Here I consider the growth of these characters in relation to shell diameter. I have already realized that a clear critical point exists at about the $6 \pi$ stage in the growth of each of these characters in $O$. puerculus (TANABE, 1975, text-fig. 8). A likewise distinct critical point is also observed at about the $6 \pi$ stage in $S$. planus.

Taking $\mathrm{R} 2110 \mathrm{~b}^{\prime}$ as an example, the growth patterns of these characters in the two species are shown in Fig. 6. As is sufficiently revealed in Fig. 6, the growth pattern of each character closely resembles between the two species, 

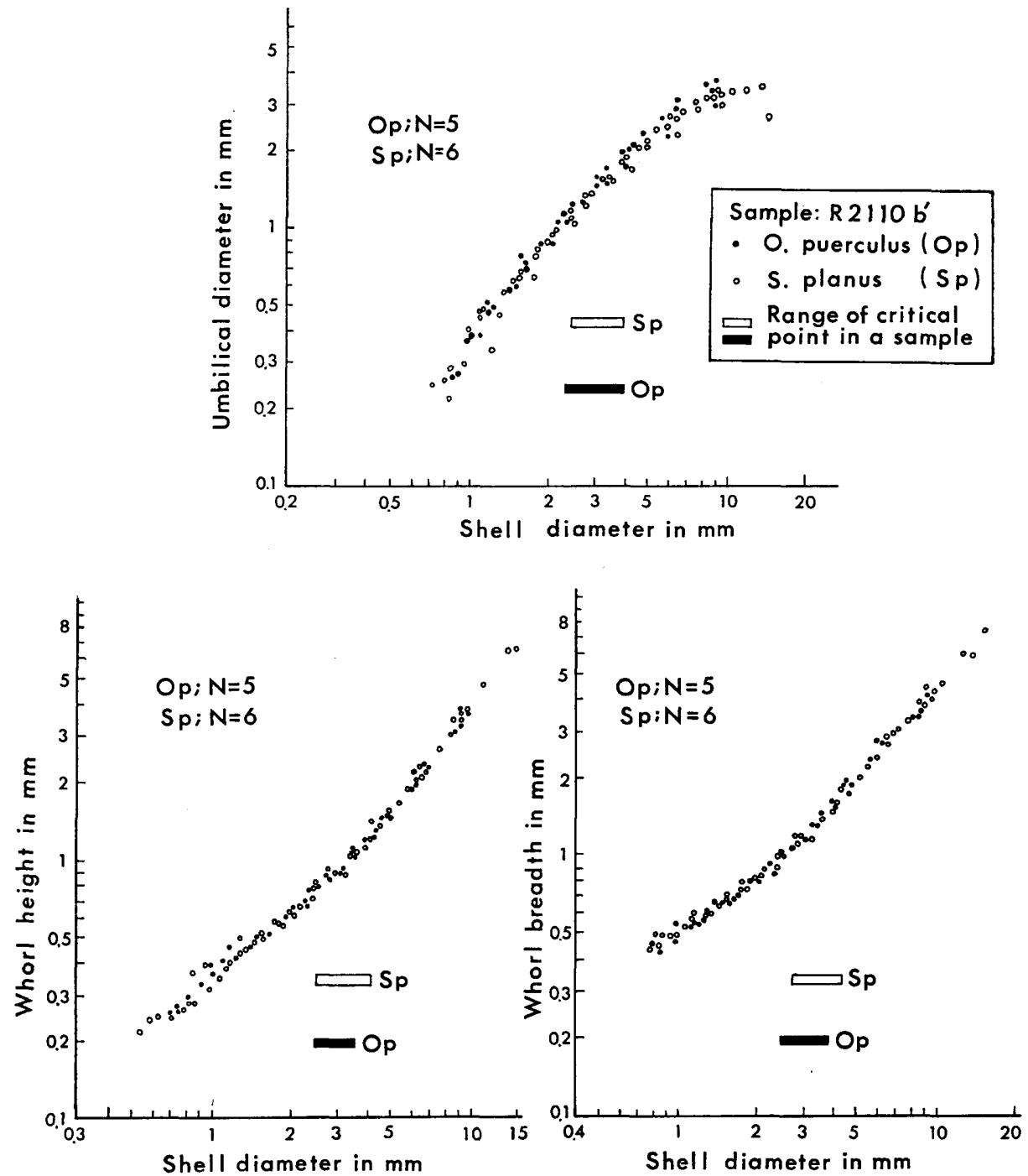

Fig. 6. Growth patterns of whorl height, breadth and umbilical diameter in relation to shell diameter in $O$. puerculus and $S$. planus from the same locality (sample, R2110b').

and the ranges of critical points overlap each other. Exceptionally, the umbilical diameter in $S$. planus abruptly decreases from about the $9 \pi$ stage (see Plate 3 ). The variation of growth ratio for each character is, hence, similar between the two species, and significant differences do not exist between the two sample means from the same localities with $95 \%$ or $99 \%$ confidence.

Growth of ventral wall thickness-Initially, I plotted each measured value on a double logarithmic graph for each sample. The results indicate that the growth pattern of the two species are very similar to each other, and moreover, a clear critical point can be observed for the samples from the lower Middle 


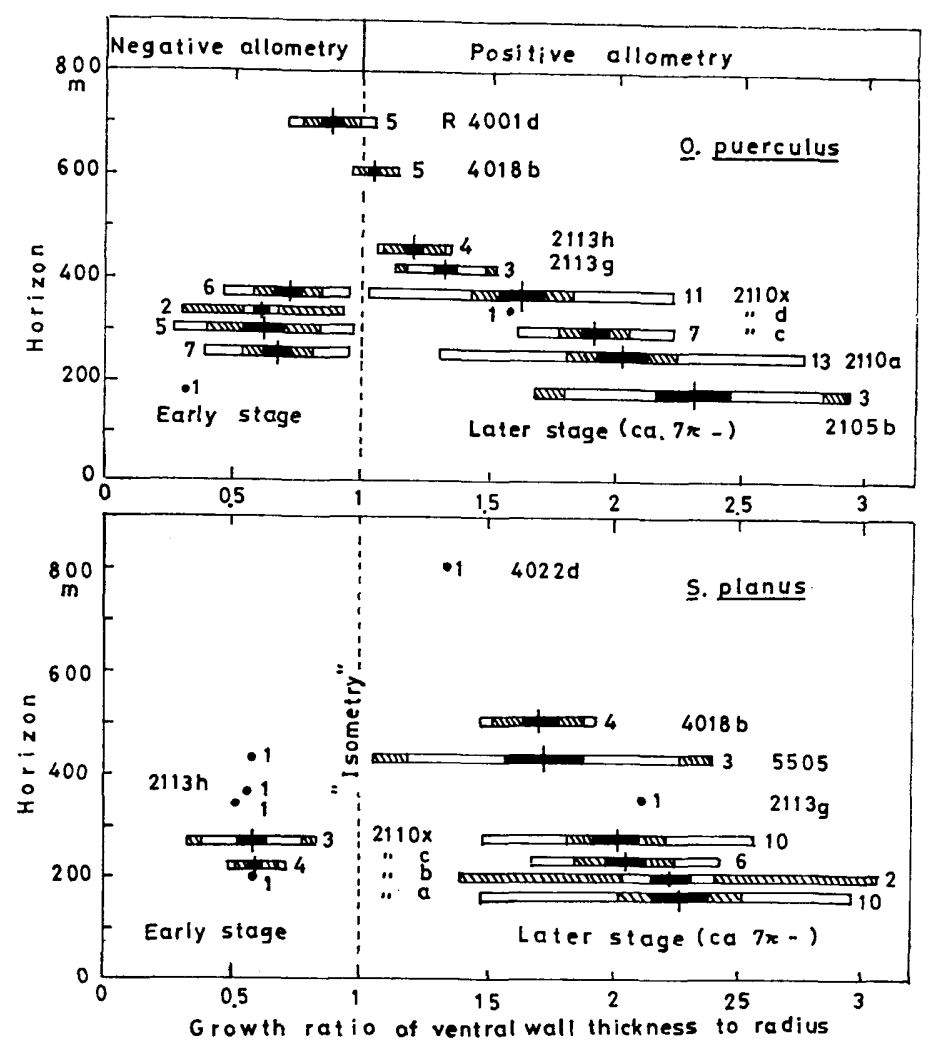

Fig. 7. Historical changes in growth ratio of ventral wall thickness to radius length of $O$. puerculus and $S$. planus in the sequence of the Obira area. Cross line, obliquely-lined rectangles, black rectangles and white rectangles express the sample mean and its $95 \%$ confidence interval, the standard error of the mean of growth ratio and two standard deviations respectively for each sample. The number beside each rectangle indicates the sample size.

Turonian. The critical point of growth in each specimen from this part is situated at about $7 \pi$ stage. However, the growth pattern of the samples from the upper Middle to the Upper Turonian indicates monophasic allometry.

Subsequently, I tried to investigate the growth ratio of ventral wall thickness to radius length using the reduced major axis method (KERMACK and HALDANE, 1950). The historical changes in the growth ratio of both species in the sequence of the Obira area are expressed in Fig. 7.

The growth ratio in the later stage (ca. $7 \pi_{-}$) of the samples from the lower Middle Turonian (O. puerculus: R 2110a-x; S. planus: R 2110a-R 5505) indicates positive allometry as against negative allometry in the early stage $(-$ ca. $7 \pi$ ). The growth ratio in the later stage of $O$. puerculus decreases with time more rapidly than that of $S$. planus, and in the samples from the upper Middle Turonian it indicates monophasic allometry (isometry or slight negative allometry). 


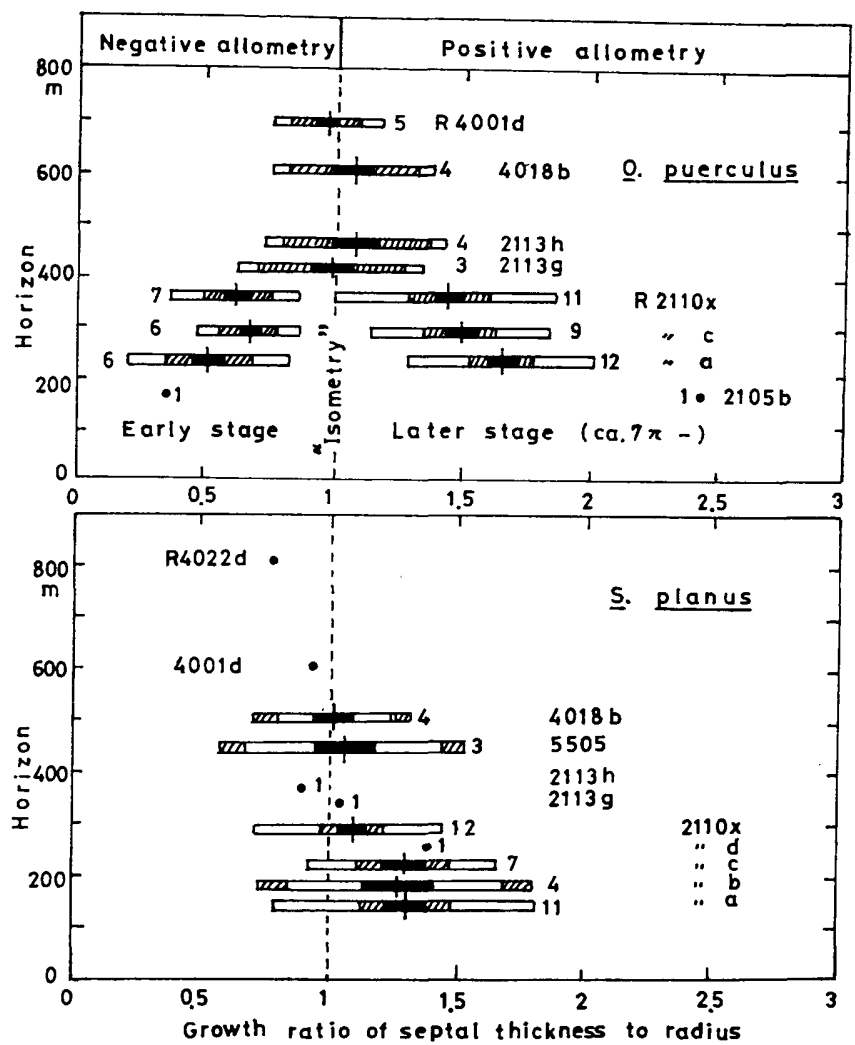

Fig. 8. Historical changes in growth ratio of septal thickness to radius length of $O$. puerculus and $S$. planus in the sequence of the Obira area. The explanation of this figure is idential with that of Fig. 7.

In the case of $S$. planus, the growth pattern in the early stage is ambiguous, because of lack of data. The mean of the growth ratio in the later stage (ca. $7 \pi-$ ) gradually decreases with time from about 2.3 to 1.5 .

The thickness of ventral wall in the two species continued to increase up to the apertural constriction, where its maximum value is indicated.

Growth of septal thickness-I examined the growth of septal thickness to radius length of the present two species after having measured the thickness at intervals of $0.5 \pi$ from the centre of coiling. In this case, each measured septum is situated near the end of each interval (see Fig. 4). Every measured value was plotted on a double logarithmic graph for each sample. A plain critical point can be observed for every specimen of $O$. puerculus from the lower stratigraphic levels (Lower to lower Middle Turonian). The situation of a critical point corresponds to about $7 \pi$ stage of each specimen. On the contrary, the growth pattern of $S$. planus indicates monophasic allometry.

I consider the growth ratio or the slope of the reduced major axis for each sample of the two species. The chronoclines in the growth ratio for the samples in the succession of the Obira area are summarized in Fig. 8. The historical 
tendency for the growth of this character fairly resembles that of ventral wall thickness.

In the case of $O$. puerculus, the growth ratio in the later stage (ca. $7 \pi^{-}$) gradually decreases with time from remarkable positive allometry $(\alpha \doteqdot 1.7)$ to isometry. The growth ratio in the early stage (0-ca. $7 \pi$ ) maintains a negative allometry.

On the other side, that of $S$. planus also gradually decreases with time from slight positive allometry to isometry or slight negative allometry.

Growth of siphuncular tube-Under the microscope the siphuncular tube of the present two species is circular in cross section, consisting of dark coloured conchiolin membrances only. This coincides with the observation on several ammonites by MUTVEI (1967) and ERBEN and REID (1971).

I examined the growth of diameter and wall thickness of siphuncular tube in relation to radius length in a certain samples. The slopes of the reduced major axes indicate that the growth of siphuncular diameter in the two species is not directly allometric (for examples, $S$. planus: $\mathrm{R} 2110 \mathrm{e}^{\prime}, \mathrm{N}=4, \bar{\alpha} \pm \mathrm{t}_{0.05} \sigma_{\alpha}=0.881 \pm 0.135$, O.R. $=0.760-0.977, \mathrm{~s}=0.10$, O. puerculus : $\mathrm{R} 2110 \mathrm{~b}, \mathrm{~N}=3, \bar{\alpha} \pm \mathrm{t}_{0.05} \sigma_{\bar{\alpha}}=0.831 \pm 0,244$, $\mathrm{O}, \mathrm{R},=0.720-0.907, \mathrm{~s}=0.10$ ) and that of wall thickness is negative allometric (for examples, $S$. planus: R $2110 \mathrm{e}^{\prime}, \mathrm{N}=1, \alpha=0.788$, O. puerculus: R $2110 \mathrm{e}, \mathrm{N}=1, \alpha=$ 0.724). The growth pattern of the two species nearly coincides with those of normally coiled ammonites, studied by WESTERMANN (1971).

Lack of a siphuncle is frequently observed in the later stage of the two species, as well as some other Mesozoic ammonoids. The reason may be the negative allometric growth and the diagenetic decrease of wall thickness, as MUtvei (1967, 1975) pointed out.

\section{B. Univariate variation}

According to the recent work on the early growth of 34 well-preserved species of ammonites by ERBEN et al. (1969), the formation of the protoconch is completed in the embryonic and larval stages and the nepionic constriction is formed in the post-larval stage. Therefore, the size of these two characters may be regarded as the object of univariate variation at a certain growth-stage. I also considered the variation of several characters in the adult shells of the two species.

Protoconch size-Maximum size of protoconch was examined in the median section of each specimen. The size ranges from $405 \mu$ to $581 \mu$ in $O$. puerculus and from $399 \mu$ to $576 \mu$ in S. planus. In every sample the coefficient of variation is relatively small $(\mathrm{V} \leqq 7.24)$. The stratigraphic changes of protoconch size of the present two species in the successions of the Obira and Oyubari areas are summarized in Fig. 9. As is obvious in this figure, the protoconch size of the two species never shows any significant difference between a pair of samples from the same localities, with $95 \%$ or $99 \%$ confidence.

Consequently, it may be concluded that the present two species show nearly the same historical fluctuation for this character.

Nepionic size-The nepionic size was also examined in the median section of each specimen. The size ranges from $714 \mu$ to $891 \mu$ in $O$. puerculus and from 

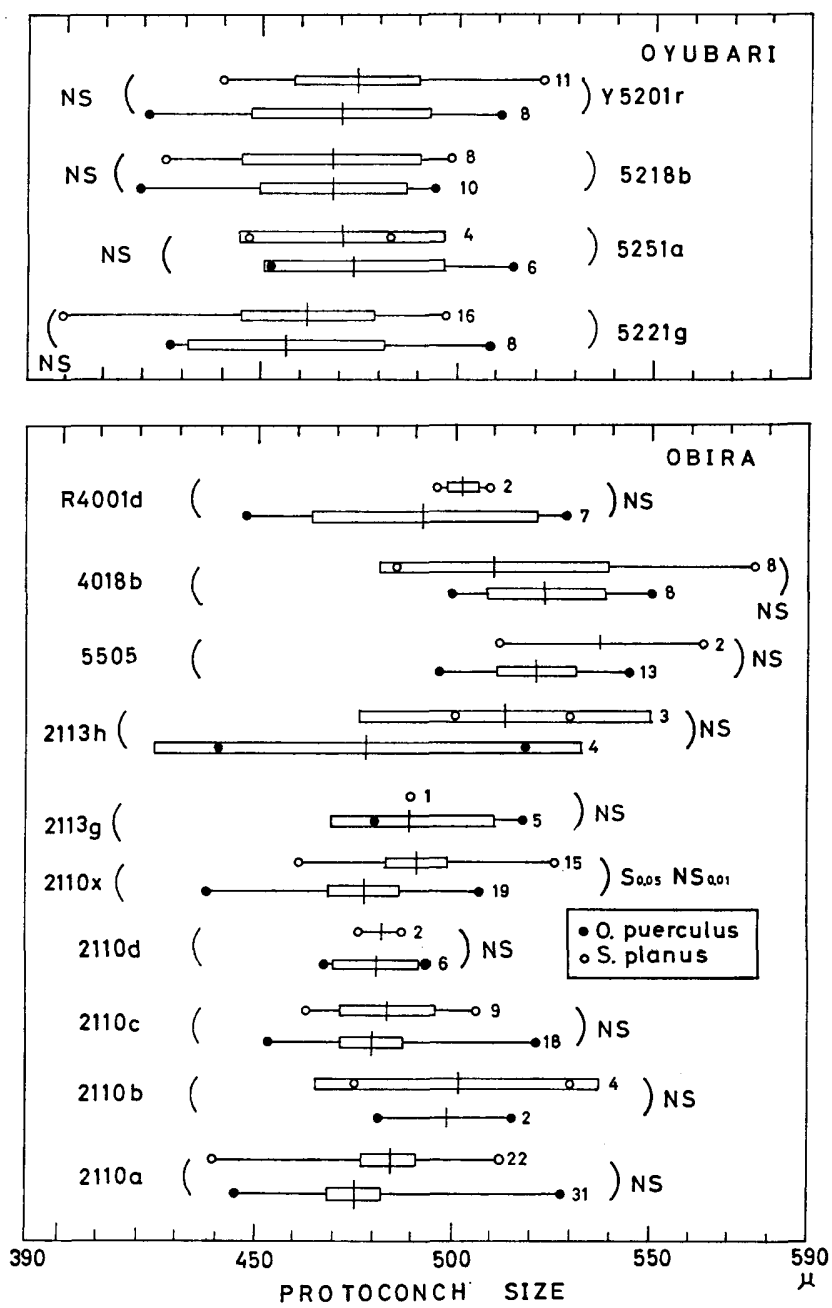

Fig. 9. Historical changes in protoconch size of $O$. puerculus and $S$. planus in the sequences of the Obira and Oyubari areas. The sample mean (cross line) and its 95\% confidence interval (white rectangles) and the observed range (horizontal line) are shown for each sample. The number beside each horizontal line indicates the sample size. The results of $t$-tests between the two means of the two species from the same localities are also shown in this figure. $\mathrm{S}_{0.05}$ : significant with $95 \%$ confidence, $\mathrm{NS}_{0.01}$ : not significant with $99 \%$ confidence, NS: not significant with 95 and $99 \%$ confidence.

$730 \mu$ to $949 \mu$ in $S$. planus. The variation in each sample is relatively small $(\mathrm{V}<7)$ as in the protoconch size. As shown in Fig. 10, with respect to the nepionic size the two species show a similar fluctuation to each other as in the case of the protoconch size.

Phragmocone size of adult shells-The variation of phragmocone size in the two species is summarized in Table 2. The variation in $S$. planus ranges from $11.7 \mathrm{~mm}$ to $24.5 \mathrm{~mm}$ and is much larger than that in $O$. puerculus $(6.9 \mathrm{~mm}-$ 


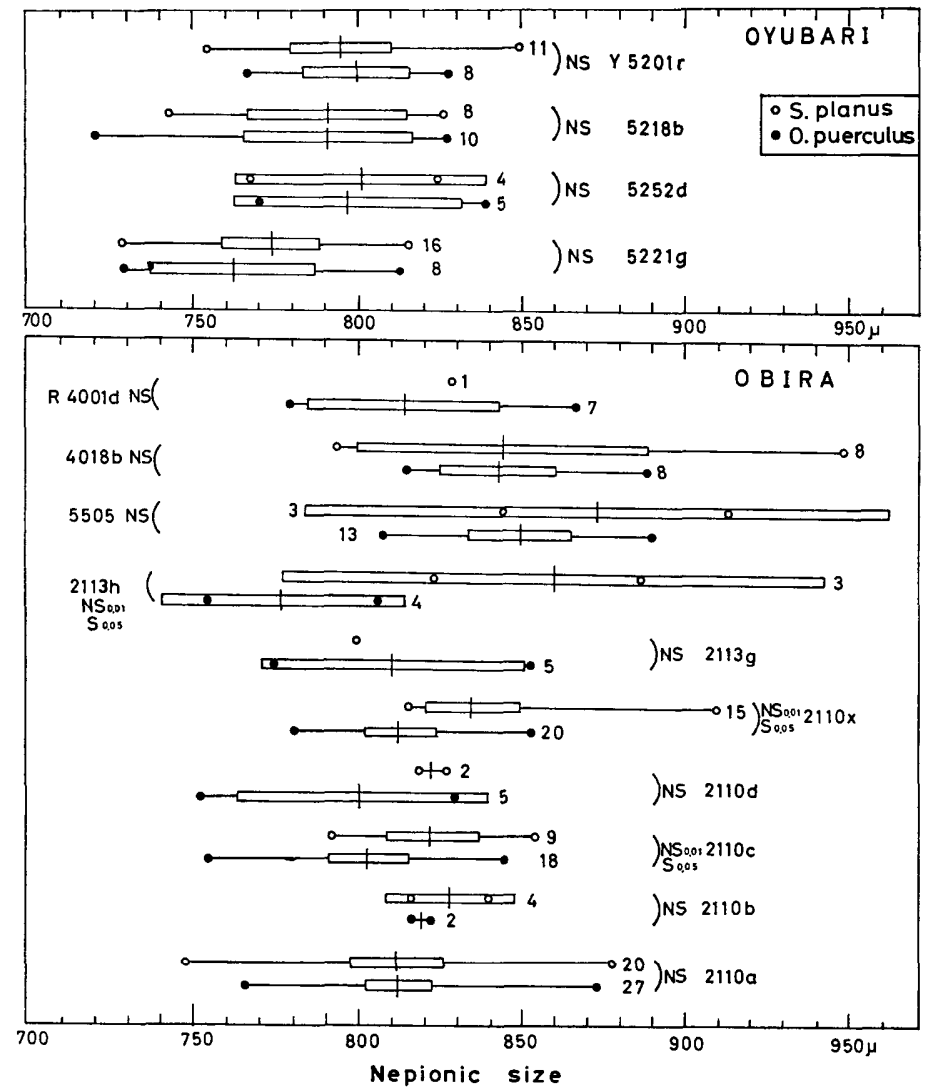

Fig. 10. Historical changes in nepionic size of $O$. puerculus and $S$. planus in the sequences of the Obira and Oyubari areas. The explanation of this figure is idential with that of Fig. 9.

$14.8 \mathrm{~mm}$ ). Phragmocone size increases phyletically, so far as the samples of the two species in the Obira and Oyubari areas are concerned.

Spiral length of phragmocone of adult shells-Spiral length of phragmocone is expressed as the total rotation angle from the centre of coiling to the base of body chamber. The variation in $O$. puerculus ranges from $7.83 \pi$ to $9.69 \pi$ $(\overline{\mathrm{X}}=8.18-9.23 \pi)$; that in $S$. planus is from $8.61 \pi$ to $10.50 \pi(\overline{\mathrm{X}}=9.08-10.03 \pi)$. In other words, the length in $S$. planus is greater than that in O. puerculus.

The variation of phragmocone length in each sample of the two species is generally small $(\mathrm{V}<6)$, and is irrespective of time.

Spiral length of body chamber of adult shells-Reconstituted spiral length of body chamber is obtained by the following method.

In the first place, I regard the length of body chamber as the half of total length of ventral and dorsal walls of body chamber. Then, the growth of spiral length of phragmocone to total rotation angle was expressed by the allometric equation for each adult specimen. Assuming that the growth of the spiral length of the phragmocone is continued up to the body chamber, I determined the 
Table 2. Phragmocone size (in micron) of adult shells in the samples of $O$. puerculus and S. planus.

\begin{tabular}{|c|c|c|c|c|c|c|c|c|c|c|}
\hline \multicolumn{6}{|c|}{ Otoscaphites puerculus (Jімво) } & \multicolumn{5}{|c|}{ Scaphites planus (YABE) } \\
\hline samples & $\mathrm{N}$ & $\overline{\mathrm{X}} \pm \mathrm{t}_{0.05} \sigma \overline{\mathrm{x}}$ & $\mathrm{V}$ & $\mathbf{s}$ & O.R. & $\mathrm{N}$ & $\overline{\mathrm{X}} \pm \mathrm{t}_{0.05} \sigma \overline{\mathrm{x}}$ & $\mathrm{V}$ & s & O.R. \\
\hline $\mathrm{N} 317 \mathrm{~d}$ & 3 & $7302 \pm 776$ & 4.28 & 312 & $6944-7517$ & & & & & \\
\hline $\mathrm{N} 315 \mathrm{~d}$ & 2 & $9072 \pm 6671$ & 8.18 & 742 & $8547-9597$ & & & & & \\
\hline $\mathrm{R} 2105 \mathrm{~b}$ & 1 & 8642 & & & & & & & & \\
\hline $\mathrm{R} 2106 \mathrm{~h}$ & 3 & $8566 \pm 1477$ & 6.94 & 595 & $8077-9228$ & & & & & \\
\hline R 2106q & 1 & 9420 & & & & & & & & \\
\hline R 2110a & 31 & $9377 \pm 186$ & 5.41 & 507 & 8353-10396 & 7 & $15696 \pm 1518$ & 10.45 & 1641 & 12980-17475 \\
\hline R $2110 \mathrm{~b}$ & 3 & $8599 \pm 2220$ & 10.39 & 893 & $8025-9628$ & & & & & \\
\hline $\mathrm{R} 2110 \mathrm{c}$ & 14 & $9397 \pm 462$ & 8.52 & 800 & 8408-10747 & 3 & $16008 \pm 1539$ & 3.87 & 620 & 15535-16709 \\
\hline $\mathrm{R} 2110 \mathrm{~d}$ & 6 & $9485 \pm 673$ & 6.76 & 641 & $8973-10650$ & 1 & 14380 & & & \\
\hline$R 2110 f$ & 2 & $8974 \pm 5216$ & 6.74 & 581 & $8563-9778$ & & & & & \\
\hline $\mathrm{R} 2110 \mathrm{x}$ & 19 & $9655 \pm 336$ & 7.22 & 697 & $8730-10948$ & 1 & 16950 & & & \\
\hline R 2113g & 4 & $10248 \pm 464$ & 2.85 & 292 & $9874-10588$ & & & & & \\
\hline R 2113h & 4 & $10814 \pm 958$ & 5.57 & 602 & 10147-11591 & & & & & \\
\hline R 5505 & 4 & $12147 \pm 1155$ & 5.98 & 726 & $11120-12800$ & 3 & $23196 \pm 2995$ & 5.20 & 1205 & $22100-24487$ \\
\hline R 4018b & 5 & $11761 \pm 1038$ & 7.11 & 837 & $10817-12882$ & & & & & \\
\hline R 4001d & 4 & $13625 \pm 2083$ & 9.61 & 1309 & $12172-14832$ & 1 & 25450 & & & \\
\hline R $4022 d$ & 1 & 14342 & & & & & & & & \\
\hline Y $5226 \mathrm{e}$ & 1 & 8654 & & & & 1 & 11445 & & & \\
\hline Y 5221g & 8 & $8735 \pm 387$ & 5.30 & 463 & $7865-9295$ & 12 & $14487 \pm 821$ & 8.92 & 1292 & $11686-16189$ \\
\hline Y 5209a & & & & & & 3 & $15608 \pm 1250$ & 2.14 & 335 & $15222-15803$ \\
\hline Y 5218b & 7 & $8539 \pm 498$ & 6.31 & 539 & $7893-9315$ & 1 & 12213 & & & \\
\hline Y 5201r & 6 & $9423 \pm 625$ & 6.32 & 596 & $8556-9985$ & 10 & $16303 \pm 517$ & 4.67 & 762 & $15568-17719$ \\
\hline Y 5201a & 1 & 11537 & & & & 2 & $16240 \pm 5778$ & 3.89 & 632 & $15793-16687$ \\
\hline
\end{tabular}

length of body chamber from the allometric equation.

Reconstituted spiral length of body chamber of the two species is summarized in Table 3. The length in $O$. puerculus is gradually shortened from about $1.5 \pi$ to $1.2 \pi$ with time in inverse proportion to the increase of phragmocone size. On the contrary, the length of $S$. planus seems to be almost unchanged (ca. 1.3 $\pi$ ) with time in the Lower to lower Middle Turonian of the Oyubari area.

Umbilical diameter of adult shells-The ratio of umbilical diameter to phragmocone was examined for each adult shell of the two species. The ratio ranges from 0.29 to 0.46 in $O$. puerculus and from 0.05 to 0.33 in $S$. planus. The coefficient of variation in each sample of $S$. planus is extremely large $(\mathrm{V}=13-86)$ as compared with that of $O$. puerculus $(\mathrm{V}=2-9)$. TANABE (1975, text-fig. 15) realized that in 0 . puerculus the ratio gradually changes from moderately evolute to moderately involute in the sequence of the Obira area.

Number of septa of adult shells-The number of septa ranges from 40 to 57 in $O$. puerculus and from 51 to 64 in S. planus. The range of variation in the two species is constant irrespective of time and the coefficient of varia- 
Table 3. Reconstituted spiral length (in $\pi$ ) of body chamber in adult specimens of $O$. puerculus from the Obira area and $S$. planus from the Oyubari area.

\begin{tabular}{|c|c|c|c|c|c|c|}
\hline & samples & $\mathrm{N}$ & $\overline{\mathrm{x}} \pm \mathrm{t}_{0.05} \sigma \overline{\mathrm{x}}$ & $\mathrm{V}$ & $\mathbf{s}$ & O.R. \\
\hline \multirow{9}{*}{ 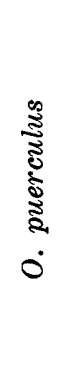 } & R $2106 \mathrm{~h}$ & 1 & 1.63 & & & \\
\hline & R 2110a & 12 & $1.37 \pm 0.07$ & 7.71 & 0.11 & $1.24-1.58$ \\
\hline & $\mathrm{R} 2110 \mathrm{c}$ & 8 & $1.31 \pm 0.07$ & 6.07 & 0.08 & $1.24-1.44$ \\
\hline & $\mathrm{R} 2110 \mathrm{~d}$ & 2 & $1.33 \pm 1.28$ & 10.76 & 0.14 & $1.23-1.43$ \\
\hline & $\mathrm{R} 2110 \mathrm{f}$ & 1 & 1.29 & & & \\
\hline & $\mathrm{R} 2110 \mathrm{x}$ & 12 & $1.29 \pm 0.05$ & 5.52 & 0.07 & $1.21-1.45$ \\
\hline & $\mathrm{R} 2113 \mathrm{~g}$ & 3 & $1.23 \pm 0.04$ & 1.14 & 0.01 & $1.21-1.24$ \\
\hline & $\mathrm{R} 2113 \mathrm{~h}$ & 2 & $1.21 \pm 0.01$ & 0.12 & 0.001 & $1.211-1.213$ \\
\hline & $\mathrm{R} 4018 \mathrm{~b}$ & 2 & $1.18 \pm 0.32$ & 3.07 & 0.04 & $1.15-1.20$ \\
\hline \multirow{5}{*}{ 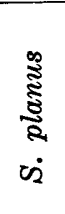 } & Y 5209a & 2 & $1.38 \pm 2.72$ & 21.90 & 0.30 & $1.17-1.60$ \\
\hline & Y 5221g & 7 & $1.53 \pm 0.22$ & 15.78 & 0.24 & $1.30-1.91$ \\
\hline & Y 5218b & 1 & 1.41 & & & \\
\hline & Y 5201r & 7 & $1.25 \pm 0.11$ & 9.29 & 0.12 & $1.11-1.43$ \\
\hline & Y 5201a & 2 & $1.29 \pm 0.18$ & 1.59 & 0.02 & $1.27-1.30$ \\
\hline
\end{tabular}

tion is relatively small in each sample of the two species.

\section{Multiple discriminant analysis}

In the previous chapters I have examined the ontogeny and variation of several characters in the present two species by the univariate and bivariate analyses. The results of ontogenetic allometry indicate that the shell morphology in the early to middle stage of the two species is similar. Significant differences in size and proportions exist, however, between the adult shells of the two species.

RAUP and MICHELSON (1965) and RAUP (1966, 1967) expressed the morphologic diversity in molluscan shells using 4 simple parameters, namely, translation, whorl expansion rate, distance of generating curve and form ratio of generating curve. As translation is zero in the planispiral ammonoids, the fundamental morphology of the present two species can be expressed by the remaining three parameters (see Fig. 4). Here I further analyse the ontogenetic change of shell form in the two species by using these three parameters.

Principal component analysis-The objective of the principal component analysis is persimonious summarization of a mass of observation (SEAL, 1964). Initially the mean vectors and the variance-covariance matrix of the three parameters, ratio of whorl breadth to whorl height, whorl expansion rate and distance of generating curve from axis at the $5 \pi, 7 \pi, 8 \pi$ and $9 \pi$ stages of the two species and the $10 \pi$ stages of $S$. planus from $R 2110 b^{\prime}$ were calculated.

The eigenvalues ( $\lambda \mathbf{i})$ and the orthogonal transformation matrix (A) of the principal components for the two species are summarized in Table 4 . The mean vector for the principal components at each stage in the two species is also shown in Table 4. The results of this analysis may imply that $3 \mathrm{~N}$ parameters 
Table 4. The eigenvectors, orthogonal transformation matrix and mean vectors of the principal components of $O$. puerculus and $S$. planus. Three parameters, namely ratio of whorl breadth to whorl height, whorl expansion rate and distance

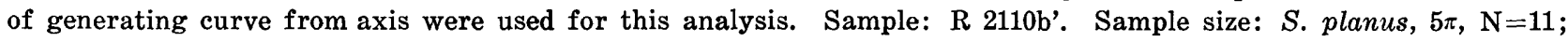
$7 \pi, \mathrm{N}=10 ; 8 \pi, \mathrm{N}=11 ; 9 \pi, \mathrm{N}=9 ; 10 \pi, \mathrm{N}=6$. O. puerculus, $5 \pi, \mathrm{N}=11 ; 7 \pi, \mathrm{N}=11 ; 8 \pi, \mathrm{N}=11 ; 9 \pi, \mathrm{N}=9$. $\lambda_{i}$; eigenvectors. (PV): percentage of total variation. A: orthogonal transformation matrix. A $\mu$ : mean vectors of principal components.

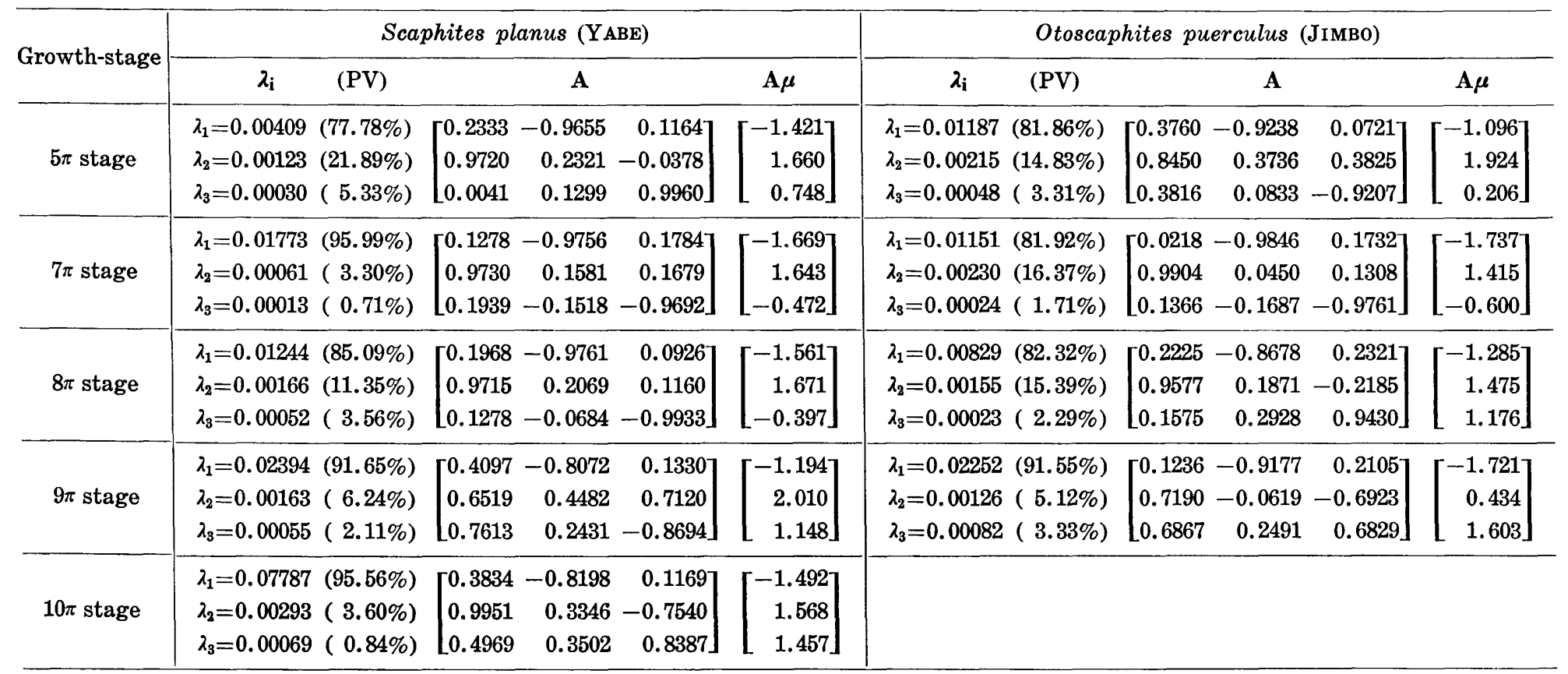




\section{Distance of generating curve from axis (C/R)}

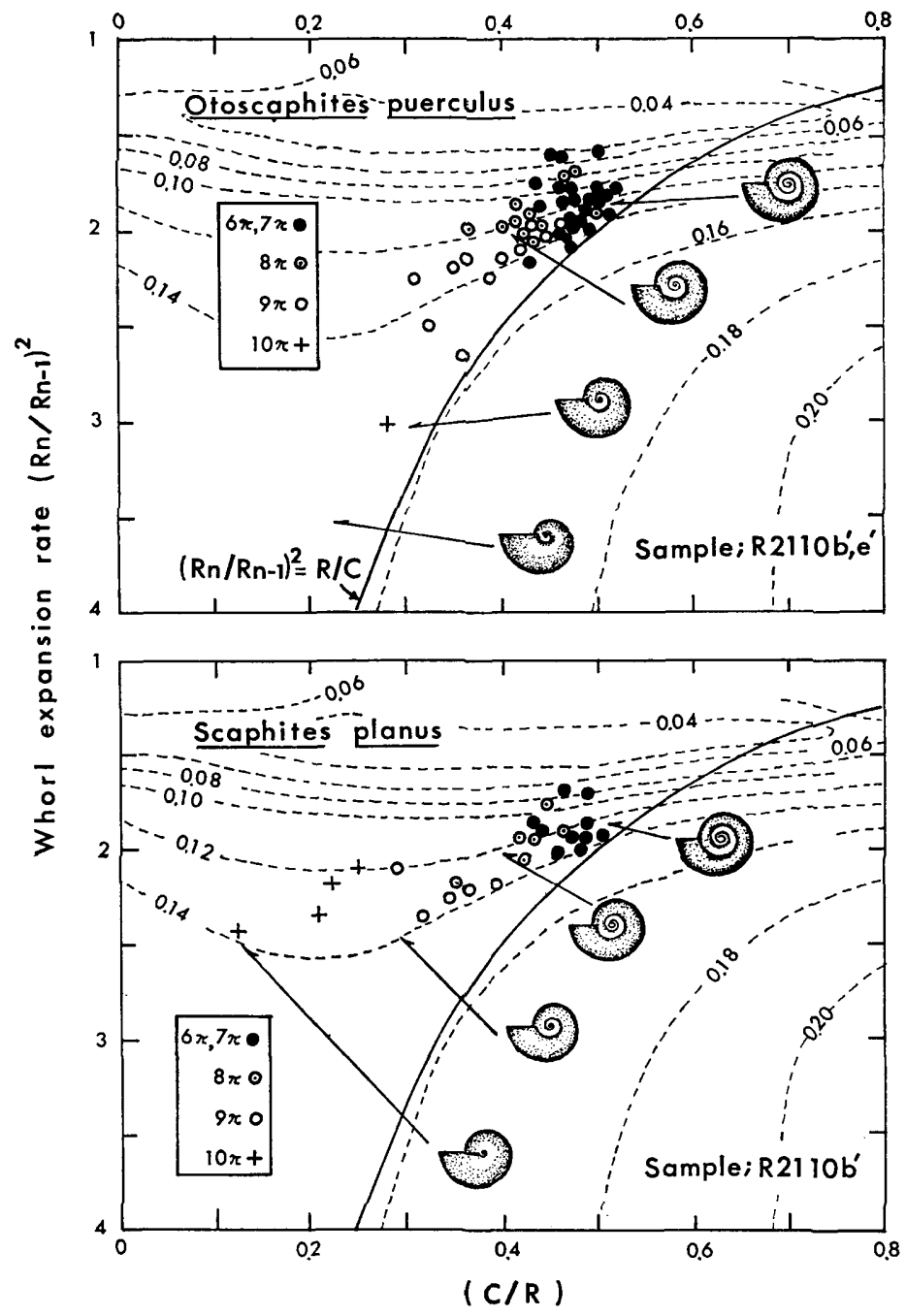

Fig. 11. Ontogenetic changes of shell morphology and stability in floating position of $O$. puerculus and $S$. planus, expressed by two simple parameters, whorl expansion rate and distance of generating curve from axis. Scale models and stability index are adopted from RAUP (1967) and RAUP and Chambelain (1967).

have been condensed into a mean vector and three eigenvalues. The first two components explain about $95-99 \%$ of the total variation. At the $5 \pi$ and $7 \pi$ growth stages the coefficients of the first and second eigenvectors and the first two mean vectors resemble each other between the two species. On the other hand, the first two mean vectors at the $9 \pi$ stage of $S$. planus are larger than those of $O$. puerculus. The reason may refer to the difference of whorl expansion rate, as indicated in Fig. 11. 
$D^{2}$ analysis-Subsequently, I investigated the difference in mean values of the above-mentioned three parameters between the present two species stage by stage with aid of Mahalanobis $D^{2}$ statistic (Mahalanobis et al., 1949). The discriminant function and the $D^{2}$ value (generalized distance) are easily calculated from the difference mean vectors and the pooled covariance matrix by the pivotal condensation method (RA0, 1952).

$$
D p^{2}=\sum_{1}^{p} \sum_{1}^{p} W^{i j}\left(\overline{\mathrm{X}}_{i 1}-\overline{\mathrm{X}}_{i 2}\right)\left(\overline{\mathrm{X}}_{j 1}-\overline{\mathrm{X}}_{j 2}\right)
$$

where $p$ is the number of variables, $W^{i j}$ is the reciprocal of the pooled covariance matrix $(i, j=1,2, \cdots, p)$. The required test criterion is given as

$$
\mathrm{F}=\frac{\mathrm{N}_{1} \mathrm{~N}_{2}\left(\mathrm{~N}_{1}+\mathrm{N}_{2}-p-1\right) D p^{2}}{p\left(\mathrm{~N}_{1}++_{2}\right)\left(\mathrm{N}_{1}+\mathrm{N}_{2}-2\right)}
$$

with a variance ratio, $p$ and $\left(\mathrm{N}_{1}+\mathrm{N}_{2}-1-\mathrm{p}\right)$ degrees of freedom. The $D^{2}$ value and the discriminant function (DF) at each stage are as follows.

$$
\begin{array}{cl}
5 \pi \text { stage: } & D^{2}=1.44 . \mathrm{F}=2.37<3.16=\mathrm{F}_{0.05(\nu=3,18)}, \mathrm{P}>0.05, \\
& \mathrm{DF}=-1.86 \mathrm{x}_{1}-69.68 \mathrm{x}_{2}-16.52 \mathrm{x}_{3} . \\
7 \pi \text { stage }: & D^{2}=2.73,3.20=\mathrm{F}_{0.05(\nu=3,17)}<\mathrm{F}=4.26<5.19=\mathrm{F}_{0.01(\nu=3,17)}, \\
& 0.05>\mathrm{P}>0.01, \mathrm{DF}=19.20 \mathrm{x}_{1}-110.15 \mathrm{x}_{2}-11.04 \mathrm{x}_{3} . \\
8 \pi \text { stage: } & D^{2}=0.09, \mathrm{~F}=0.15<3.16=\mathrm{F}_{0.05(\nu=3,18)}, \mathrm{P}>0.05, \\
& \mathrm{DF}=-2.81 \mathrm{x}_{1}-0.43 \mathrm{x}_{2}-3.32 \mathrm{x}_{3} . \\
9 \pi \text { stage: } & D^{2}=2.64,3.34=\mathrm{F}_{0.05(\nu=3,14)}<\mathrm{F}=3.45<5.56=\mathrm{F}_{0.05(\nu=3,14)}, \\
& 0.05>\mathrm{P}>0.01, \mathrm{DF}=41.75 \mathrm{x}_{1}-5.62 \mathrm{x}_{2}+9.80 \mathrm{x}_{3} . \\
\text { Adult stage }(O . \text { puerculus, } 9 \pi: \text { S. planus, } 10 \pi): \quad D^{2}=52.13, \\
\\
\mathrm{~F}=53.95>6.22=\mathrm{F}_{0.01(\nu=3,14)}, \mathrm{P}<0.01, \\
\mathrm{DF}=125.49 \mathrm{x}_{1}-203.85 \mathrm{x}_{2}-66.37 \mathrm{x}_{3} .
\end{array}
$$

At each of the 5, 7, 8 and $9 \pi$ growth-stages, the difference in mean values between the two species is not significant, with $95 \%$ or $99 \%$ confidence. On the contrary, $D^{2}$ value at the adult stage is very large as compared with those of young to middle stages, and the difference between the two species is significant with $99 \%$ confidence.

Consequently, the results of $D^{2}$ analysis may indicate that the difference in form between the present two species does not appear until the adult stage.

\section{Suture Development}

It has long been stated that ammonoid sutures are one of the most important taxonomic characters because of their stability and regulation (SCHINDEWOLF, 1960 ; KullmanN and Wiedmann, 1970). Among many Cretaceous ammonoids, the Scaphitidae are good examples whose sutures had evolved finely (CoBbAN, 1951; WIEDMANN, 1965, 1969).

According to WIEDMANN (1965), the suture evolution in the scaphitids is expressed by the lengthening of saddles from the primary suture, E L U I. 
S. planus
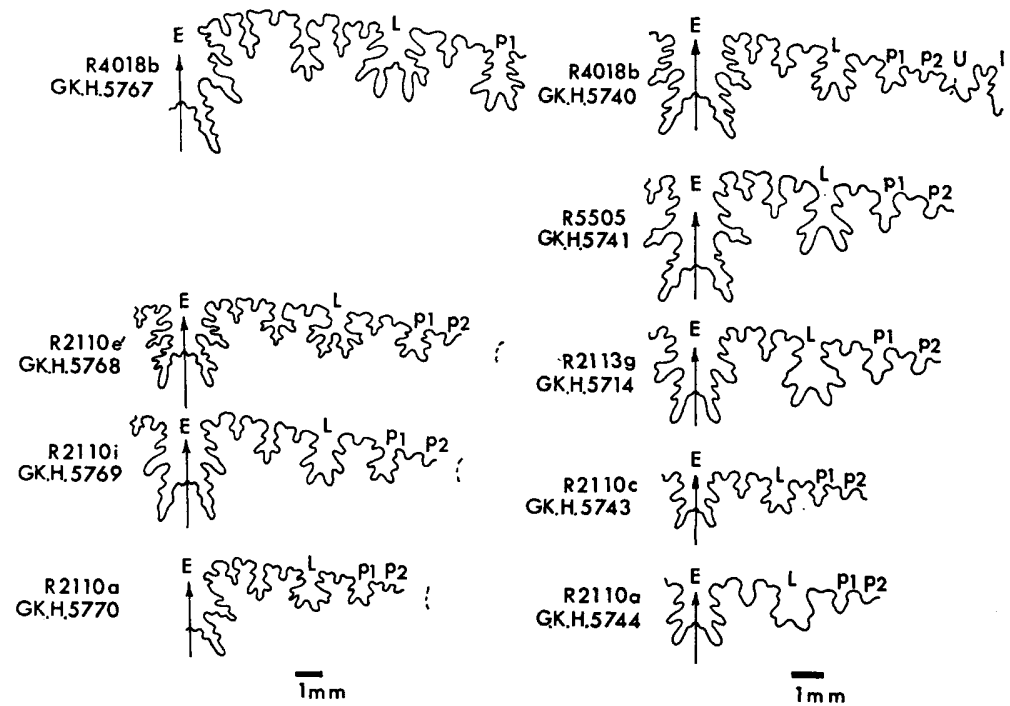

Fig. 12. Trends of evolution of adult sutures of $O$. puerculus and $S$. planus in the sequence of the Obira area.

Hence, he proposed a new element, pseudolobes (symbol p), for a few incisions of saddle L $U$ that originated from the saddle frills of the root form, Eoscaphites.

A similar increase in the subdivision and depth of incision is observed in the lineages of the two species. The evolutionary patterns of adult sutures in the succession of the Obira area are summarized in Fig. 12. In every case the adult suture of the two species is expressed by the formula, $E \mathrm{~L} \mathrm{p} \mathrm{p}_{2} \mathrm{Uv} U \mathrm{Ud}$. Although $\mathrm{p}_{1}$ of $S$. planus is essentially quadrifid as against trifid $\mathrm{p}_{1}$ of $O$. puerculus, each element of the two species is gradually complicated with time.

Subsequently, I observed the ontogenetic suture development of the two species. The trends of the development in the succession of the Obira area are summarized in Fig. 13. $p_{1}$ and $p_{2}$ appear progressively earlier with time in the two species, and the evolutionary rate of 0 . puerculus is more rapid than that of $S$. planus. Until about the $8 \pi$ stage the shape of each element is fundamentally similar to each other. So far as I have examined, the variation of sutures at any stage in each sample is generally small.

I next examined the growth of half length of suture in the two species in relation to total rotation angle, by the least square method. The results are summarized in Fig. 14. The growth ratio of $O$. puerculus increases with time in accordance with the increase of the initial growth index. On the other hand, that of $S$. planus increases with time with the decrease of the initial growth index. It is very interesting that an intimate relationship between the suture complexity and the growth of septal and ventral wall thickness is observed in the two species. Namely, the suture complexity increases with time in accordance with the decrease of growth ratio of shell thickness. Furthermore, a prominent critical point can be observed at the $7 \pi$ stage in the suture growth of $R 2110 b^{\prime}-1$ 

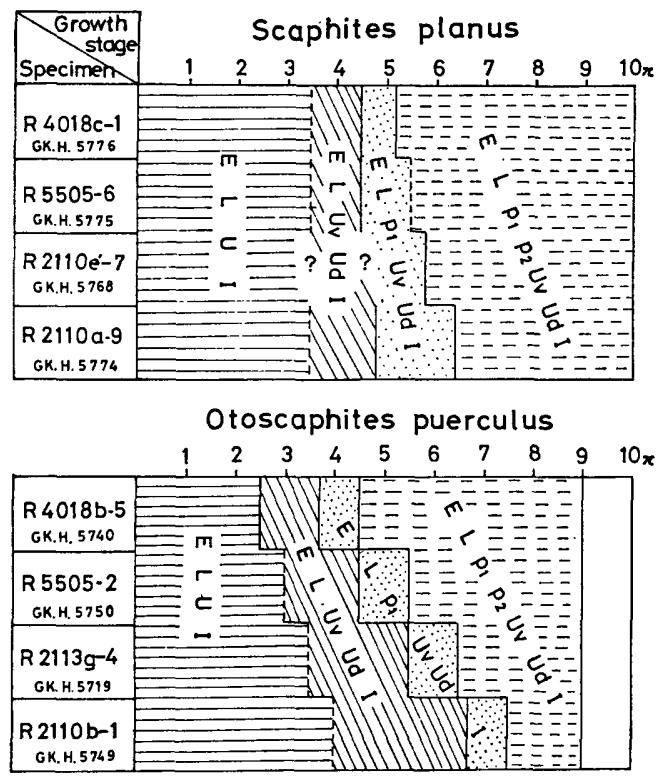

Fig. 13. Trends of evolution of ontogenetic suture development of $O$. puerculus and $S$. planus in the sequence of the Obira area.

(GK. H. 5749) (see Fig. 14) of O. puerculus. From this stage, the growth ratio abruptly decreases from 0.203 to 0.121 . In the samples from the same horizon as $\mathrm{R} 2110 \mathrm{~b}^{\prime}$, this stage nearly corresponds to the range of critical points of the specimens where the growth of ventral wall and septal wall thickness changes from negative to positive allometry (see Figs. 7-8).

SEILACHER (1975) mentioned that the evolution of ammonitic sutures in several stocks has reduced the unsupported areas in the phragmocone wall to a minimum, allowing further thinning of the outer wall. The above-mentioned growth pattern of sutures in the present two species may support SEILACHER's interpretation.

\section{Functional Evolution}

\section{A. Evolution of buoyancy}

Denton and GILPIN-Brown (1961a, b, 1966, 1971, 1973), Denton et al. (1967) and CoLLINS and MINTON (1967) determined the mechanism of buoyancy control in such modern chambered cephalopods as Nautilus, Sepia and Spirula. According to their works, those animals can control the volume of the gas space within the chambers by altering the amount of liquid present via the siphuncle whose wall is permeable to fluids. Denton and GILPIN-Brown (1973) concluded that the role of the siphuncle in buoyancy control in chambered cephalopods had remained the same in a great variety of forms over most of the history of the group.

Supposing that the above-mentioned function of chambered shell and 

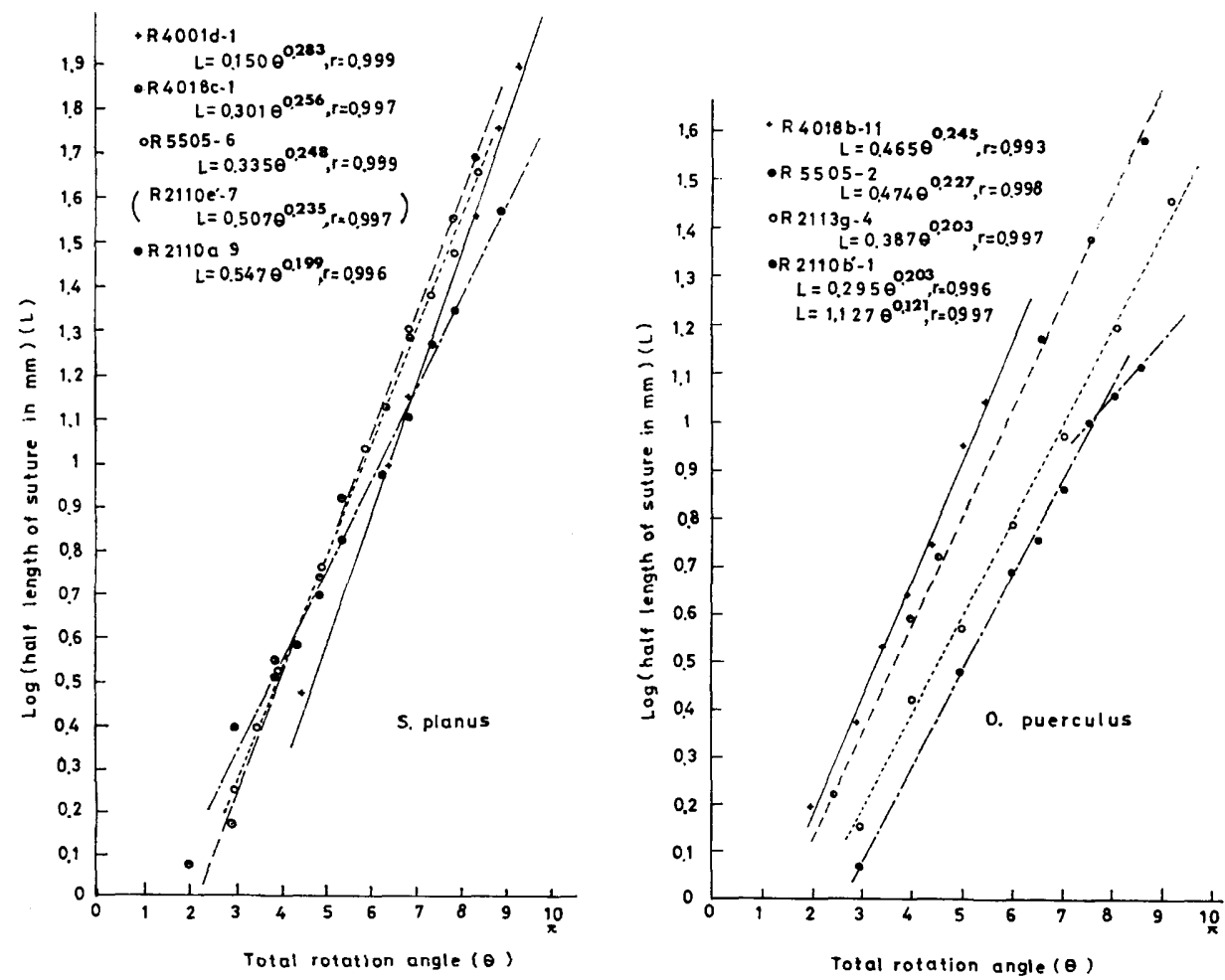

Fig. 14. Growth patterns of half length of sutures to total rotation angle in the selected specimens of $O$. puerculus and $S$. planus from the Obira area.

siphuncle can be applied to the case of ammonoids, I here discuss the evolution of buoyancy in the present two species.

The phragmocone size of adult shells of the two species increases gradually with time in accordance with the increase of growth ratio of radius length to total rotation angle in the 4th growth-phase from 5.5 $\pi$. However the number of septa and spiral length of phragmocone do not change with time. These lines of evidence imply that the cameral volume of adult shells increases gradually with time.

The growth ratio of septal and ventral wall thickness to radius length in the later stage (ca. 7.5 $\pi$-) gradually decreases with time from positive allometry to isometry or slight negative allometry. Therefore, the relative weight of the shell material to the shell volume of the two species decreases with time. The above-mentioned phyletic tendency suggests that the buoyancy of the two species gradually increases with time.

In order to quantify this tendency, I calculated the approximate buoyancy of several adult shells of the two species. The density of an empty ammonoid shell is expressed as follows.

$$
\frac{\rho \mathrm{s} \cdot \mathrm{Vs}}{\rho \mathrm{w} \cdot(\mathrm{Vt}-\mathrm{Vb})}
$$


where Vt is total volume of water displaced by a shell plus animal, $\mathrm{Vb}$ is volume of animal, assumed to be equivalent to that of body chamber, Vs is volume of shell material, $\rho \mathrm{w}$ is the density of sea water $(=1.03)$ and $\rho \mathrm{s}$ is the density of shell material, assumed to be 2.62 (REYMENT, 1958, 1973).

A neutrally buoyant ammonoid shell is given by the following condition.

$$
\frac{\rho \mathrm{s} \cdot \mathrm{Vs}}{\rho \mathrm{w} \cdot(\mathrm{Vt}-\mathrm{Vb})-(\mathrm{V} p \cdot \rho \mathrm{w}) \cdot \mathrm{Fs}}=\rho \mathrm{w},
$$

where Vp is cameral volume and Fs is flooding limit necessary to sink an empty shell. Fs may be extracted from equation (1).

$$
\mathrm{Fs}=\left[\rho \mathrm{w}^{2} \cdot(\mathrm{Vt}-\mathrm{Vb})-\rho \mathrm{s} \cdot \mathrm{Vs}\right] / \mathrm{Vp} \cdot \rho \mathrm{w}^{2} .
$$

Using this formula, I calculated Fs for several adult shells of O. puerculus (TANABE, 1975, table 5).

However, if we discuss the buoyancy of living ammonoids, we should take into account the weight of septa, siphuncle and soft parts. In my previous work, I neglected the weight of these characters.

According to DENTON and GILPIN-BROWN (1973), almost all modern cephalopod tissues are slightly denser than sea water (e.g. Nautilus macromphalus: 1.067). This means that the soft part of cephalopods is one of the important sinking components. TRUEmaN (1941) weighted several septa and siphuncle of such Jurassic ammonites as Promicroceras marstonense, Dactylioceras commune and Ludwigia baylei. In these ammonites the proportions of weight of septa and siphuncle are about $3-6 \%$ and $1 \%$ of the total shell weight respectively. I measured the weight and volume of certain parts of a shell on several specimens of Nautilus pompilius from the vicinity of Mindanao Island, Philippine. The results indicate that the weight of siphuncle is only about $0.1-0.2 \%$ of the total shell weight. The proportion of weight of septa to total shell weight is about 15-19\%. The latter value is somewhat larger than Trueman's estimation on Jurassic ammonites.

In order to estimate the proportion of weight of septa to total shell weight in the present two species, I compared the growth of septal thickness to ventral wall thickness in the two species with that in $N$. pompilius. The growth ratio of the two species indicates slight negative allometry to isometry in the selected samples (for examples, $O$. puerculus: $\mathrm{R} 2110 \mathrm{a}, \mathrm{N}=5, \bar{\alpha}=0.975, \mathrm{~V}=12.7, \mathrm{~s}=0.124$; $\mathrm{R} 4018 \mathrm{~b}, \mathrm{~N}=3, \bar{\alpha}=1.016, \mathrm{~V}=15.9, \mathrm{~s}=0.161 ;$ S. planus: $\mathrm{Y} 5221 \mathrm{~g}, \mathrm{~N}=4, \bar{\alpha}=0.841$, $\mathrm{V}=11.8, \mathrm{~s}=0.099)$. On the other hand, in $N$. pompilius growth is slightly positively allometric (Mindanao sample, $\mathrm{N}=3, \bar{\alpha}=1.123, \mathrm{~V}=3.84, \mathrm{~s}=0.043$ ).

$N$. pompilius has simple concave septa as against the complicated fluted septa in ammonoids. However, WESTERMANN (1975) realized that septa in Upper Cretaceous Pachydiscus decrease in thickness peripherally at a similar rate as fluting increases.

This evidence means that if we take the weight excess owing to septal fluting into consideration, the proportion of septal weight to total shell weight in the present two species may less than the value in $N$. pompilius. 
Table 5. Approximate calculation of density of several adult shells of $O$. puerculus and S. planus. Vc: cameral volume in disregard of septal volume. $\mathrm{Vb}$ : volume of body chamber, assumed to be equivalent to that of soft part. Vsw: volume of shell wall. Vs $(5 \%)$ and Vs (15\%) are volume of septa supposing to be $5 \%$ and $15 \%$ of total shell volume respectively. $\mathrm{D}(5 \%)$ and $\mathrm{D}(15 \%)$ are shell densities under the conditions, Vs (5\%) and Vs (15\%) respectively. Fs is proportion of flooding necessary to sink each living shell.

\begin{tabular}{|c|c|c|c|c|c|c|c|}
\hline Species & Specimens & $\mathrm{Vc}$ & $\mathrm{Vb}$ & Vsw & $\mathrm{Vs}(15 \%)$ & $\mathrm{Vs}(15 \%)$ & $\mathrm{D}(5 \%) \& \mathrm{Fs} \mathrm{D}(15 \%) \& \mathrm{Fs}$ \\
\hline \multirow{8}{*}{$\begin{array}{l}\text { O. puer } \\
\text { culus }\end{array}$} & $2110 \mathrm{~b}^{\prime}-1$ & $0.18 c . c$. & 0.41 c.c. & 0.081c.c. & 0.004c.c. & 0.014 c.c. & $0.885(0.209) \quad 0.982(0.073)$ \\
\hline & -2 & 0.18 & 0.45 & 0.078 & 0.004 & 0.014 & $0.871(0.226) \quad 0.970(0.089)$ \\
\hline & -3 & 0.19 & 0.48 & 0.094 & 0.005 & 0.017 & $0.947(0.123) 1.055(-)$ \\
\hline & -4 & 0.16 & 0.51 & 0.090 & 0.005 & 0.016 & $1.040(-) 1.153(\square)$ \\
\hline & -5 & 0.14 & 0.45 & 0.080 & 0.004 & 0.014 & $1.045(\square) 1.160(\square)$ \\
\hline & -6 & 0.22 & 0.51 & 0.103 & 0.005 & 0.018 & $0.907(0.178) 1.010(0.032)$ \\
\hline & $4018 b-1$ & 0.39 & 0.74 & 0.111 & 0.006 & 0.020 & $0.647(0.485) \quad 0.718(0.410)$ \\
\hline & -2 & 0.42 & 0.76 & 0.126 & 0.007 & 0.022 & $0.670(0.463) 0.740(0.378)$ \\
\hline \multirow{2}{*}{$\begin{array}{l}\text { S. Y } \\
\text { planus }\end{array}$} & Y $5221 \mathrm{~g}-1$ & 0.20 & 0.90 & 0.105 & 0.006 & 0.019 & $1.032(\square) 1.140(\square)$ \\
\hline & -2 & 0.34 & 1.15 & 0.152 & 0.008 & 0.027 & $0.911(0.170) 1.009(0.031)$ \\
\hline
\end{tabular}

Consequently, I calculated the revised densities of several adult specimens of the two species, assuming that the density of soft tissues is 1.067 and the proportions of septal volume are $5 \%$ and $15 \%$ of the total shell volume respectively. The revised density of a living ammonoid is given by

$$
\frac{\rho \mathrm{VVs}-\mathrm{Vb} \cdot(1.067-\rho \mathrm{w})}{\rho \mathrm{w} \cdot(\mathrm{Vt}-\mathrm{Vb})} .
$$

I formerly estimated the volume of shell material in $O$. puerculus supporing the shell to be a cone with a circular cross section (TANABE, 1975, p. 126). In that work, I neglected the evidence that the shell wall thickness grows exponentially in relation to the length of whorl; accordingly the shell density of the selected specimens is too large as compared with that of sea water. It is very important for considering the volume of shell wall that the thickness of shell wall abruptly increases from negative allometry to strong positive allometry from about $7.5 \pi$ stage in the specimens of the two species from the lower Middle Turonian (see Fig. 7). The above-mentioned evidence may indicate that a simple cone model cannot be adopted in the two species for the estimation of shell wall volume.

Consequently, I calculated again the volume of selected adult specimens of the two species, assuming each specimen to be a combination of a cone and a semi-cone, divided at the $7.5 \pi$ stage. The results of the buoyancy calculations of the two species are summarized in Table 5.

In the specimens of the two species from the lower horizons ( $R 2110 b^{\prime}$ and $Y$ 5221g), their shell densities are nearly equal to or slightly larger than that of sea water under non-flooded conditions. On the contrary, two specimens of O. puerculus from the upper horizon ( $R 4018 \mathrm{~b}$ ) are of a lower density than sea water. 


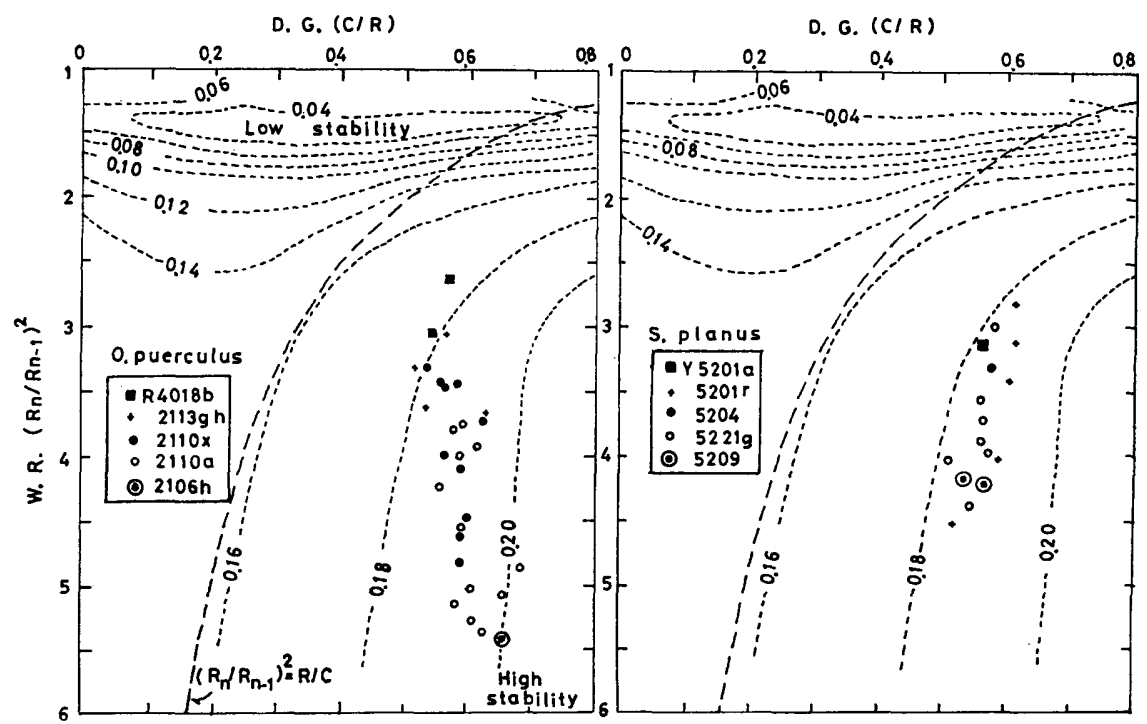

Fig. 15. Historical changes in morphology and stability in floating position of adult shells of $O$. puerculus and $S$. planus in the sequences of the Obira and Oyubari areas.

The results of the buoyancy calculation may give the seal that the present two species had evolved gradually in the direction of a buoyancy excess.

\section{B. Evolution of stability}

Reconstruction of the stability of ammonoid shells is important for the determination of their life position and swimming ability.

RAUP (1967) and RAUP and ChamberlaiN (1967) gave the method to determine the centres of gravity and buoyancy, and graphically illustrated the stability of many ammonoid shells using two simple parameters, whorl expansion rate and distance of generating curve from axis. They simulated each ammonoid shell as having a circular cross section and a constant shell thickness. According to their method, the stability index is expressed by the distance between the centre of gravity and that of buoyancy, divided by the shell diameter. Applying this method to the present two species, I examined the stability index of each shell. The ontogenetic changes of the two species are shown in Fig. 11. During the normally coiled stage, the stability of the two species is nearly constant (0.12-0.14). On the contrary, the stability of both species changes abruptly from about the $10 \pi$ stage to the adult stage with the change of shell morphology from normal to abnormal coiling (see Fig. 15). The stability index of the adult specimens of $O$. puerculus from the Obira sequence gradually decreases with time from about 0.20 to 0.17 . In the case of $S$. planus, it is constant (0.18-0.19) in the sequence of the Oyubari area.

\section{Evolution in mode of life}

In this chapter I discuss the evolution in mode of life of $O$. puerculus and 
S. planus, based on such indirect kinds of evidence as the results of morphologic analysis, buoyancy calculation and mode of occurrence.

The considerably large shell densities of the adult specimens of the two species from the lower Middle Turonian under the non-flooding condition seems to indicate that their chambered shells may not have been so effective for the buoyancy control. In the case of Nautilus macromphalus, the densities of shell minus liquid are about 0.90 to 0.91 , slightly less than that of sea water, and the living shell maintains neutral buoyancy with about $10 \%$ flooding (DENTON and GILPIN-Brown, 1966).

Judging from the crowded mode of occurrence and good preservation of apertures in addition to the comparison of shell densities between the present two species and $N$. macromphalus, the mode of life in the adult stage of the two species from the lower Middle Turonian may have been mainly benthic, even if they could swim slowly. On the other hand, the two adult shells of O. puerculus from the upper horizon ( $R$ 4018b) approach neutral buoyancy with $39-49 \%$ flooding. If we take the error owing to the application of a hypothetical shell model to the actual shell into consideration, the two specimens had densities less than that of sea water. Probably, O. puerculus changed its mode of life in the adult stage, from benthic to planktic or nektic with time, in accordance with the increase of buoyancy. A low density similar to that of $O$. puerculus from $\mathrm{R} 4018 \mathrm{~b}$ is known in several normally coiled ammonites (HePtonstall, 1970 ; Raup, 1973; REYMENT, 1973; MUtVei and REYMENT, 1973).

With respect to $S$. planus from the upper stratigraphic levels, I did not calculate the shell buoyancy. The changes of growth pattern of septal and ventral wall thickness to radius length with time shows the same tendency as those of $O$. puerculus. Accordingly, it may be postulated that the mode of life in the adult stage of $S$. planus from the upper part of the Turonian was planktic or nektic as in $O$. puerculus. However, a high stability in the adult shells of the two species throughout the Turonian may imply that they could not swim so quickly as many normally coiled ammonoids. In all probability, the capacity for locomotion was mainly restricted to the vertical direction (planktic mode of life) for the adult specimens of the two species from the upper part of the Turonian.

During the normally coiled stage of the two species, the growth of septal and ventral wall thickness to radius length indicates isometry or slight negative allometry. Furthermore, in the specimens from the upper horizons, a clear critical point exists at about the $7.5 \pi$ stage in the growth of these two characters. Unfortunately, I have observed no perfectly preserved body chamber in the young shells of the two species. But some young shells have a body chamber longer than $2 \pi$. If we assume the length of body chamber of young shells to be $2 \pi$, the $7.5 \pi$ stage may correspond to the base of the body chamber at the stage when the growth of whorl changes from normal to abnormal coiling.

It has been known that there is an isometric or slightly negative allometric relationship between many of the dimensions of coiled ammonoid shells (OBATA, 1959; REYMENT and SANDERBERG, 1963; WestermanN, 1971). The above- 


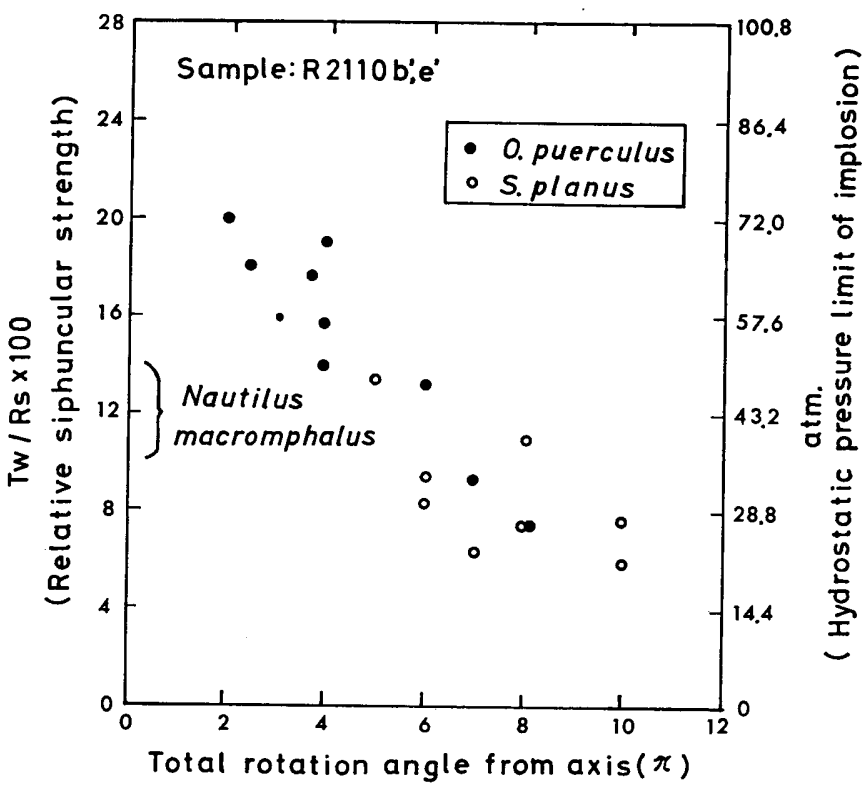

Fig. 16. Ontogenetic changes in relative siphuncular strength and assumed hydrostatic pressure limit of implosion of $O$. puerculus and S. planus. Tw: thickness of siphuncular wall, Rs: radius of siphuncular tube. Hydrostatic pressure limit is estimated supposing the tensile strength of siphuncular tube wall of the two species to be equivalent to that of Nautilus macromphalus $\left(36 \mathrm{Kg} / \mathrm{cm}^{2}\right.$; DeNToN and GILPIN-Brown, 1966).

mentioned characteristic of growth pattern of septal and ventral wall thickness may suggest that the mode of life in the normally coiled stage of the present two species was nektic throughout Turonian.

The crowded occurrence may also imply that the two species were prolific as compared with other ammonites from the Upper Cretaceous of Hokkaido and south Sakhalin. Moreover, the occurrence of the two species is restricted in the silty mudstone facies of the selected areas studied. Probably their habitats were limited within a relatively narrow space.

\section{Siphuncular strength and depth range}

Here I briefly discuss the siphuncular strength and depth range of the two species.

DENTON and GILPIN-Brown (1961a, b, 1966, 1971, 1973) made clear that the total gas pressure within the chambers of Nautilus, Sepia and Spirula is always at less than atomospheric pressure (e.g. N. macromphalus; ca. $0.91 \mathrm{~atm}$.) regardless of the depth at which each animal lives. This fact means that each shell must be strong enough to withstand the hydrostatic pressure equivalent to the maximum depth at which each animal can lives. DENTON and GILPINBrown (1966, 1971), RAUP and TAKahashi (1966) and Collins and Minton (1967) demonstrated experimentally that the siphuncle of Nautilus and Spirula 


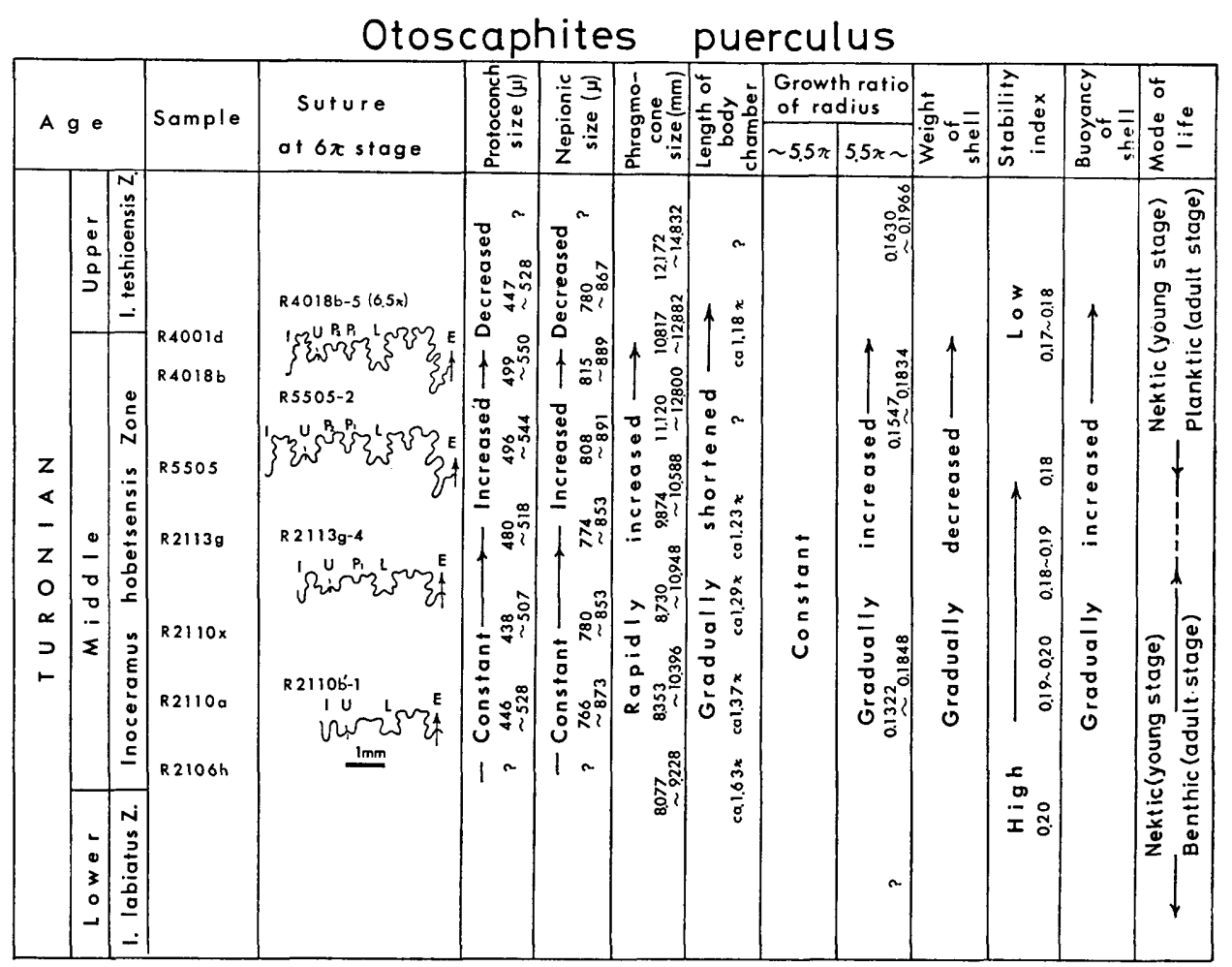

Fig. 17. Functional evolution of Otoscaphites puerculus (JIMBo) in the Turonian sequence of the Obira area.

is the weakest part within the shell. DENTON and GILPIN-Brown (1966) also developed a method for calculating the siphuncular strength of Nautilus. According to them, the hydrostatic pressure limit $(\rho)$ of implosion is given by the following formula.

$$
\rho=k \cdot \frac{\mathrm{Tw}}{\mathrm{Rs}},
$$

where $k$ is the tensile strength of siphuncle, Tw is the thickness of the siphuncular wall and $R s$ is the radius of the siphuncular tube. They gave a tensile strength of $35-37 \mathrm{~kg} / \mathrm{cm}^{2}$ for the siphuncle of $N$. macromphalus.

WESTERMANN (1971) estimated the siphuncular strength of several Mesozoic ammonites by using the parameter, $\mathrm{Tw} / \mathrm{Rs} \times 100$ (his relative siphuncular strength). He determined the strength of Lytoceratina and Phylloceratina as about 10 to 19, stronger than that of the Ammonitina (3-6.5).

We should estimate the siphuncular strength of ammonoids after due consideration of the diagenetic decrease of the siphuncular wall thickness. Based on the data on Nautilus pompilius, MUTVEI (1975) suggested that the diagenetic decrease of wall thickness of the horny tube in ammonoids has been $50 \%$ or more. Therefore, I calculated the relative siphuncular strength of the present 
Scaphites planus

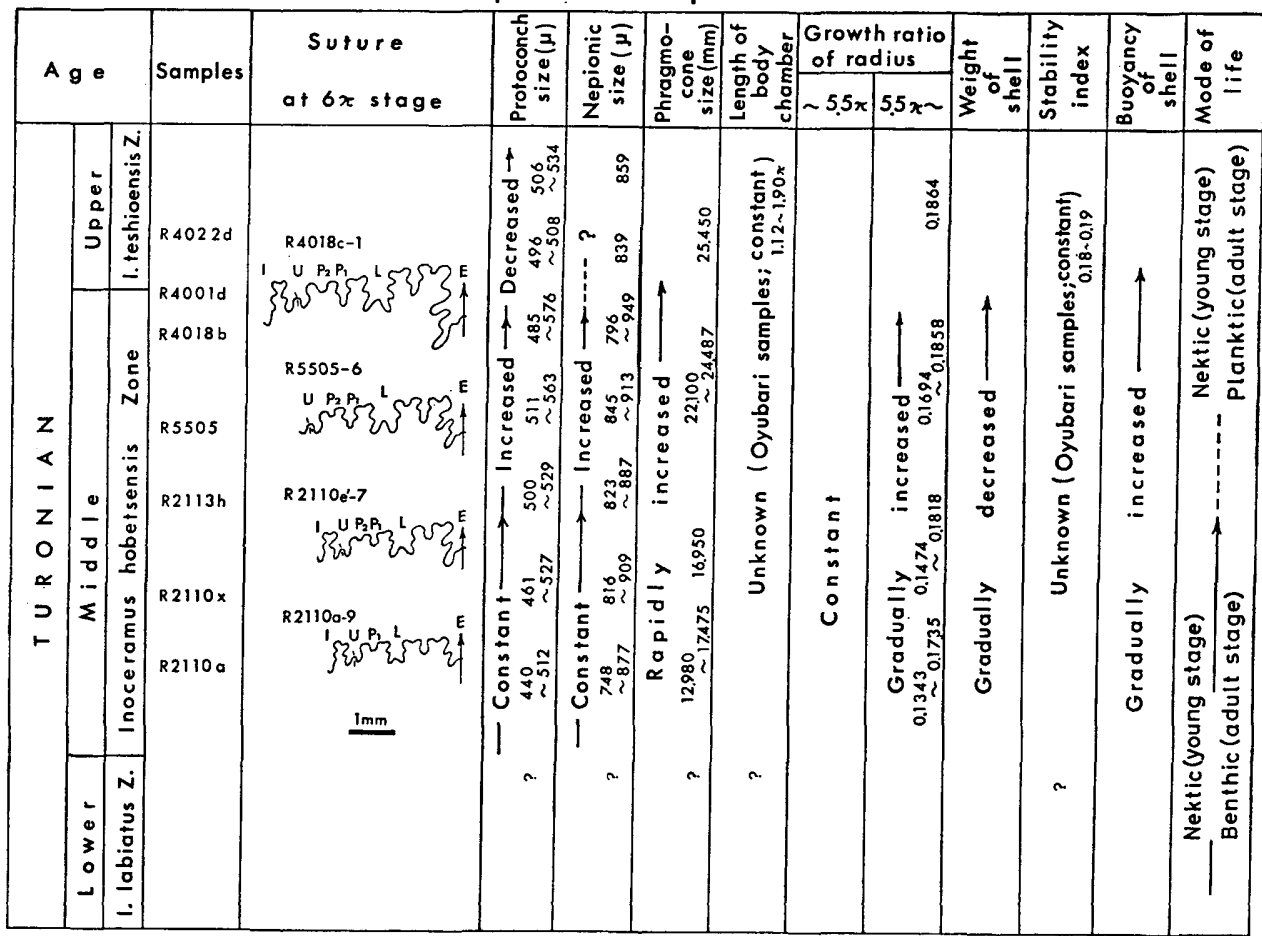

Fig. 18. Functional evolution of Scaphites planus (YABE) in the Turonian sequence of the Obira area.

two species on the basis of an original wall thickness of twice the observed thickness. The results are summarized in Fig. 15.

The low value in the later stage may imply that the depth ranges of adult of the two species were less than that of Nautilus macromphalus (0-ca. $600 \mathrm{~m}$; DENTON and GILPIN-BRown, 1973). If we assume the tensile strength of the siphuncular wall in the two species was equivalent to that of $N$. macromphalus, the bathymetric limit of siphuncle implosion in the adult stage is estimated at about $200 \mathrm{~m}$ through $300 \mathrm{~m}$.

The functional evolution of the present two species are summarized in Figs. 17-18 respectively.

\section{Taxonomic Positions}

Here I discuss the taxonomic relationship between $O$. puerculus and $S$. planus, and the problem of sexual dimorphism.

As outlined in the preceding chapters, the geographic and stratigraphic distribution of the two species are quite identical. The growth patterns of radius length, whorl height and breadth, umbilicus and ventral wall and septal thickness are also closely similar until about the $9 \pi$ stage. Moreover, the evolutionary patterns of several shell characters and of the sutures are alike in the 
two. The similarity of suture patterns may indicate that the two species are taxonomically related to each other.

There are several differences such as shell size, apertural shape, rate of involution, spiral length of phragmocone, number of septa and complexity of adult sutures between the adult shells of the two species.

Makowski (1962), Calloman (1963), WestermanN (1964), Houša (1965) and CoBBAN (1969) reported numerous examples of dimorphism in adult ammonites. According to them, dimorphism is mainly expressed in differences of size and form, and the small form is regarded as the male and the large one as the female. A pair of lateral lappets or ventral rostrum are frequently observed in the small form. PaLframaN (1969) mentioned that the lateral lappets, existing on the small forms, may have been organs, related to sexual activity. Alternatively, MAтsumoтo et al. (1972) mentioned that the lateral lappets may have been connected with diversity in habitats and mode of life rather than sexual activity. At present any functional or taxonomic meanings of lappets have not yet been clarified; accordingly, it is perhaps questionable to regard lappets as diagnostic of males.

Two ideas have been presented on sexual dimorphism in the Scaphitidae. MAKowski (1962), HoušA (1965) and CoBBAN (1969) pointed out that sexual dimorphism is expressed by size difference between large and small forms and existence of umbilical swellings on large form.

In the meanwhile, WIEDMANN (1965) proposed the possibility of sexual dimorphism between large forms with simple apertures (his Scaphites (s.s.)) and lappeted small forms (his S. (Otoscaphites), S. (Hyposcaphites) and $S$. (Pteroscaphites)).

I could not find any discontinuous variation in $S$. planus depending on size difference and existence of umbilical swellings. The stage of development of umbilical swellings in $S$. planus varies from specimen to specimen.

Consequently, the above-mentioned similarities between the present two species may suggest the possibility of sexual dimorphism. However, in this study I cannot decide whether the similarities between the two species may be the result of sexual dimorphism or evolutionary convergence from polyphyletic origins. More complete data on the significance of lappets, in addition to researches on the dimorphism in modern cephalopods are needed to decide between the alternative interpretations given above.

\section{Explanation of Plate 62}

\section{All figures $\times 2$}

Figs. 1-9. Otoscaphites puerculus (JiмBo) ............................. 401 Two lateral (a,c), frontal (b) and ventral (d) views are shown for each adult specimen. Arrows point to the base of body chamber.

1 , GK. H. 5752, sample R $2110 e^{\prime}$. 2, GK. H. 5753, sample R $2110 e^{\prime}$. 3, GK. H. 5710, sample R 2110a. 4, GK. H. 5755, sample R 2110b'. 5, GK. H. 5754, sample T 1079 p. 6, GK. H. 5756, sample R 2248 p. 7, GK. H. 5712, sample R 2110b. 8, GK. H. 5715, sample R 2110c. 9, GK. H. 5719, sample R $2113 \mathrm{~g}$. 

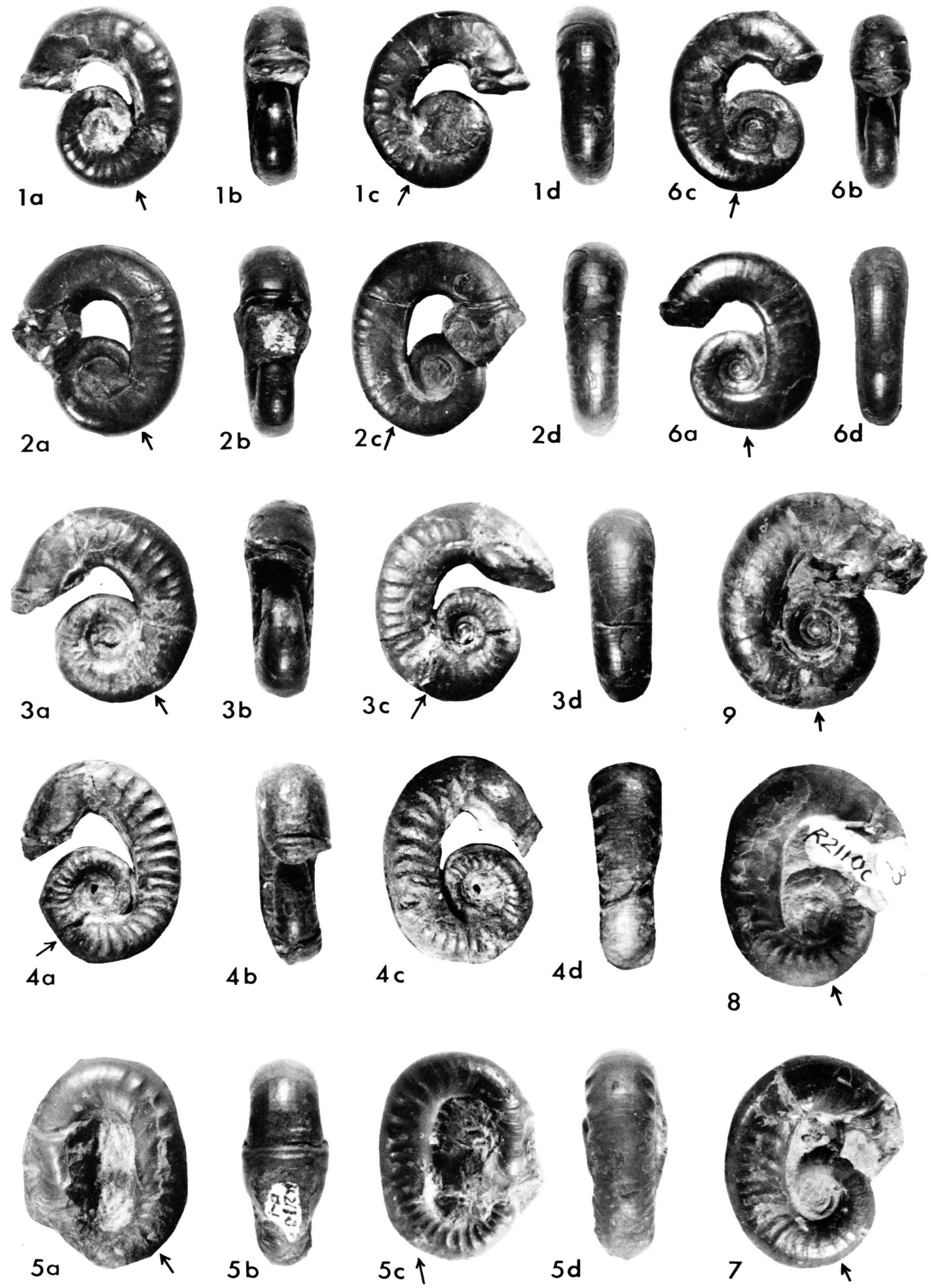

K. TANABE: Functional Evolution of Otoscaphites and Scaphites 
Mem. Fac. Sci., Kyushu Univ., Ser. D, Vol. XXIII

Plate 63
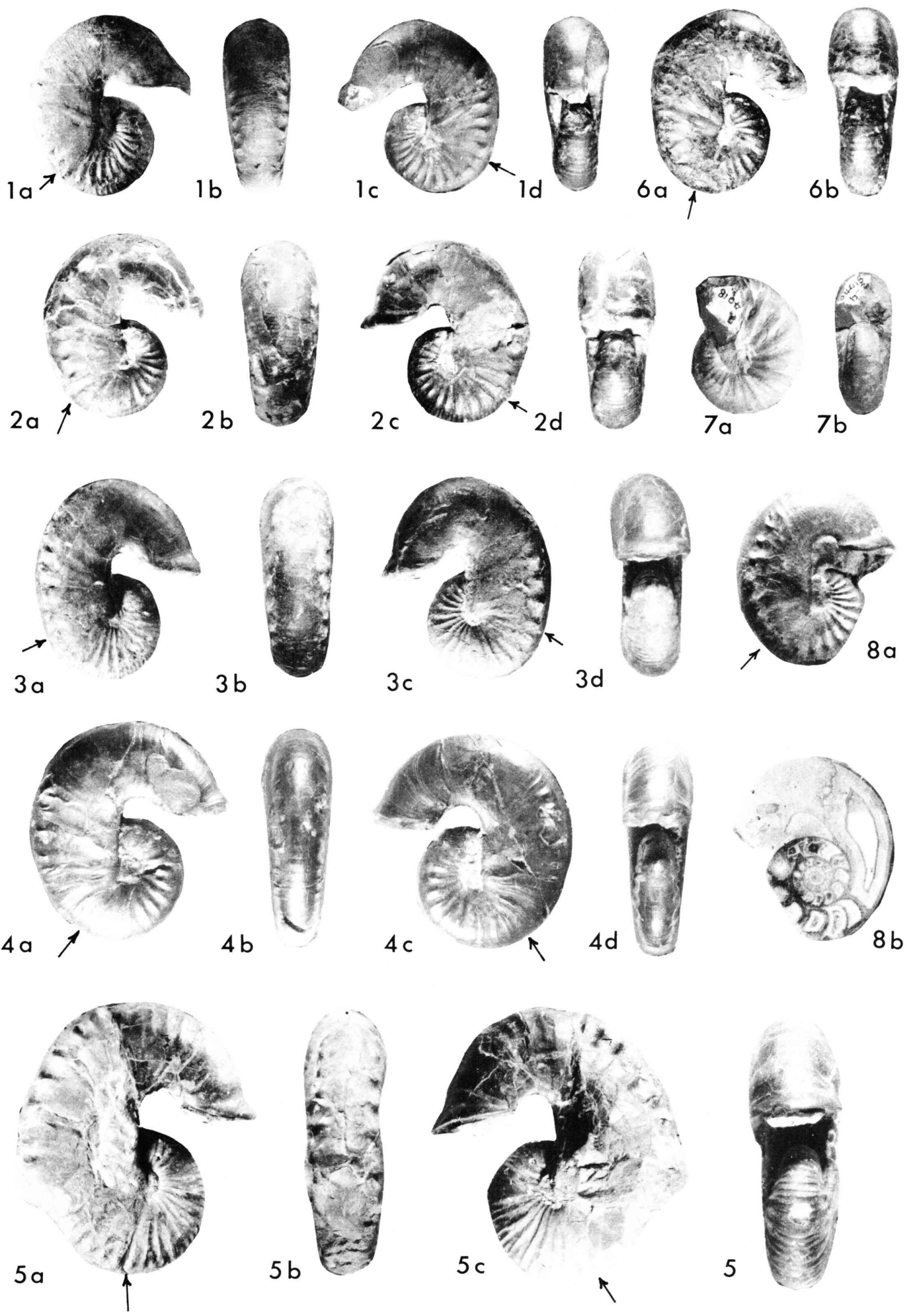

K. Tanabe: Functional Evolution of Otoscaphites and Scaphites 
Superfamily Scaphitaceae MEEK, 1876

Family Scaphitidae MeEK, 1876

Genus Otoscaphites WRIGHT, 1953

Type-species.-Ammonites bladenensis SCHLÜTER, 1871

Otoscaphites puerculus (JIMBo)

Pl. 62, Figs. 1-9; Pl. 64, Figs. 1-5

1894. Scaphites puerculus Jimbo, Palaeont. Abh. Neue Folge, Bd. 2, Heft 3, p. 37 , pl. 5, fig. 4 .

? 1902. Scaphites inermis Anderson, Proc. Calif. Acad. Sci., Ser. III, vol. 2, no. 1. p. 113, pl. 3, figs. 74-77.

1910. Yezoites puerculus (JimBo): YABE, Beitr. Paläont. Geol. Oesterr.-Ungarns $u$. des Orients, vol. 23, p. 170-171, pl. 15, figs. 20-22.

1910. Yezoites puerculus (JIMBO) var. teshioensis YABE, op. cit., p. 171-172, pl. 15, figs. 23-27.

1953. Otoscaphites puerculus (YABE): Wright, Ann. Mag. Nat. Hist., Ser. 12, vol. 6, p. 475.

? 1958. Scaphites inermis ANderson, Geol. Soc. Amer., Special Papers, no. 16, p. 251, pl. 27, figs. 1, 1 a-c.

1963. Otoscaphites puerculus (JiмBo): Matsumoto, Palaeont. Soc. Japan, 24th Anniv. Vol., p. 44, pl. 6, fig. 4.

non 1965. Scaphites puerculus Jimbo: Verechagin et al., A Field Atlas of the Cretaceous Fauna from Northeast Soviet Socialist Republics, p. 42, pl. 33, fig. 4.

non 1965. Scaphites (Otoscaphites ?) puerculus Jimbo: Windmann, Palaeontology, vol. 8 , pt. 3 , p. $433-434$, text-fig. 9 ; pl. 59, figs. $1-2$.

1975. Otoscaphites puerculus (Jimbo): TANABe, Trans. Proc. Palaeont. Soc. Japan, N. S., no. 99, pp. 109-132, pls. 10-11.

Type.-MAтsumoto (1963) designated Jiмво's (1894) illustrated specimen from the Pankemo-yubari River, Oyubari area, as the lectotype. The specimen is stored in the University Museum of the University of Tokyo with the registered number, GT I-120 (=MM 7520).

Remarks.-Scaphites inermis ANDERSON $(1902,1958)$ from the Upper Cretaceous

\section{Explanation of Plate 63}

All figures in natural size

Figs. 1-8. Scaphites planus (Y Two lateral (a,c), frontal (b) and ventral (d) views are shown for each adult specimen, except otherwise stated. Arrows point to the base of body chamber.

1, GK. H. 5777, sample R 2110b'. 2, GK. H. 5778, sample R 4511p. 3, GK. H. 5779, sample Y 5256a. 4, GK. H. 5780, sample R 2112p. 5, GK. H. 5781, sample R 5505. 6, Lateral (a) and frontal (b) views of GK. H. 5782, sample R 2110i. 7, Lateral (a) and frontal (b) views of GK. H. 5783 (immature shell), sample $R 4018$ b. 8, Lateral view (a) and median section (b) of GK. H. 5784, Loc.: Near the Tengunosawa River of the Obira area (in a river gravel), K. Asano (Tohoku University) coll. 
of Oregon, closely resembles the present species in the marginal outline and surface ornament. YABE (1910) and MATSUMоTо (1959b) regarded S. inermis as identical with $O$. puerculus. ANDERson's descriptions are, however, too poor for precise comparison of the Oregon species with the present species.

It has long been believed that the present species ranges up to the Coniacian (Yabe, 1910; Matsumoto, 1943). Formerly, Wright (1953) and TANABE (1975) pointed out that the Japanese Coniacian "puerculus" was more strongly ornamented than the Turonian species. Recently, TANABE (1977) realized that the Coniacian Otoscaphites from north Pacific region include O. klamathensis (ANDERSON) and O. matsumotoi TANABE.

S. puerculus Jimbo (VEREChAGIN et al., 1965) from the "Coal Bay", northeast coast of Siberia, is probably a synonym of $O$. matsumotoi.

$S$. (O. ?) puerculus Jimbo (WIEDMANN, 1965) from the Upper Turonian of Shasta County, California, may be attributed to $O$. bladenensis ScHLÜTER because of the degree of development of the adult suture.

YABE's (1910) var teshioensis may be included in the large from of the present species.

Geographic distribution.-The present species occurs abundantly in various areas of Hokkaido and south Sakhalin.

\title{
Genus Scaphites PaRKInson, 1811
}

Type-species.—Scaphites equalis J. SowERBY, 1811

\author{
Scaphites planus (YABE) \\ Pl. 63, Figs. 1-8; P1. 64, Figs. 6-9
}

? 1902. Scaphites condoni Anderson, Proc. Calif. Acad. Sci., Ser. III, III, vol. 2, p. 111, pl. 2, figs. 58-63.

1910. Yezoites planus YABE, Beitr. Paläont. Geol. Oesterr.-Ungarns u. des Orients, vol. 23, p. 167-169, pl. 15, figs. 11-18.

1910. Yezoites planus var. gigas YABE, op. cit., pl. 15, fig. 19.

non 1920. Scaphites planus Roman and Mazeran, Mus. Hist. Nat. Lyon Archives, vol 12, Mem. 2, p. 13, pl. 4, figs. 15-17.

? 1958. Scaphites condoni Anderson, Geol. Soc. Amer., Special Papers, no. 16,

\section{Explanation of Plate 64}

\author{
All figures $\times 6$ \\ Each specimen was cut in parallel to the base of body chamber.
}

Figs. 1-5. Otoscaphites puerculus (JIмв0) ........................... 401 1-5, adult shells. 1, GK. H. 5730, sample R 2110b'. 2, GK. H. 5757, sample R 2110c'. 3, GK. H. 5732, sample R 2110b'. 4, GK. H. 5731, sample R 2110e'. 5, GK. H. 5758, sample R $2110 \mathrm{e}^{\prime}$.

Figs. 6-9. Scaphites planus (Y 6, adult shell. 7-9, immature shells. 6, GK. H. 5785, sample R $2110 b^{\prime}$. 7, GK. H. 5786, sample R $2110 b^{\prime}$. 8, GK. H. 5787, sample R 2110b'. 9, GK. H. 5788, sample $R 2110 \mathrm{e}^{\prime}$. 

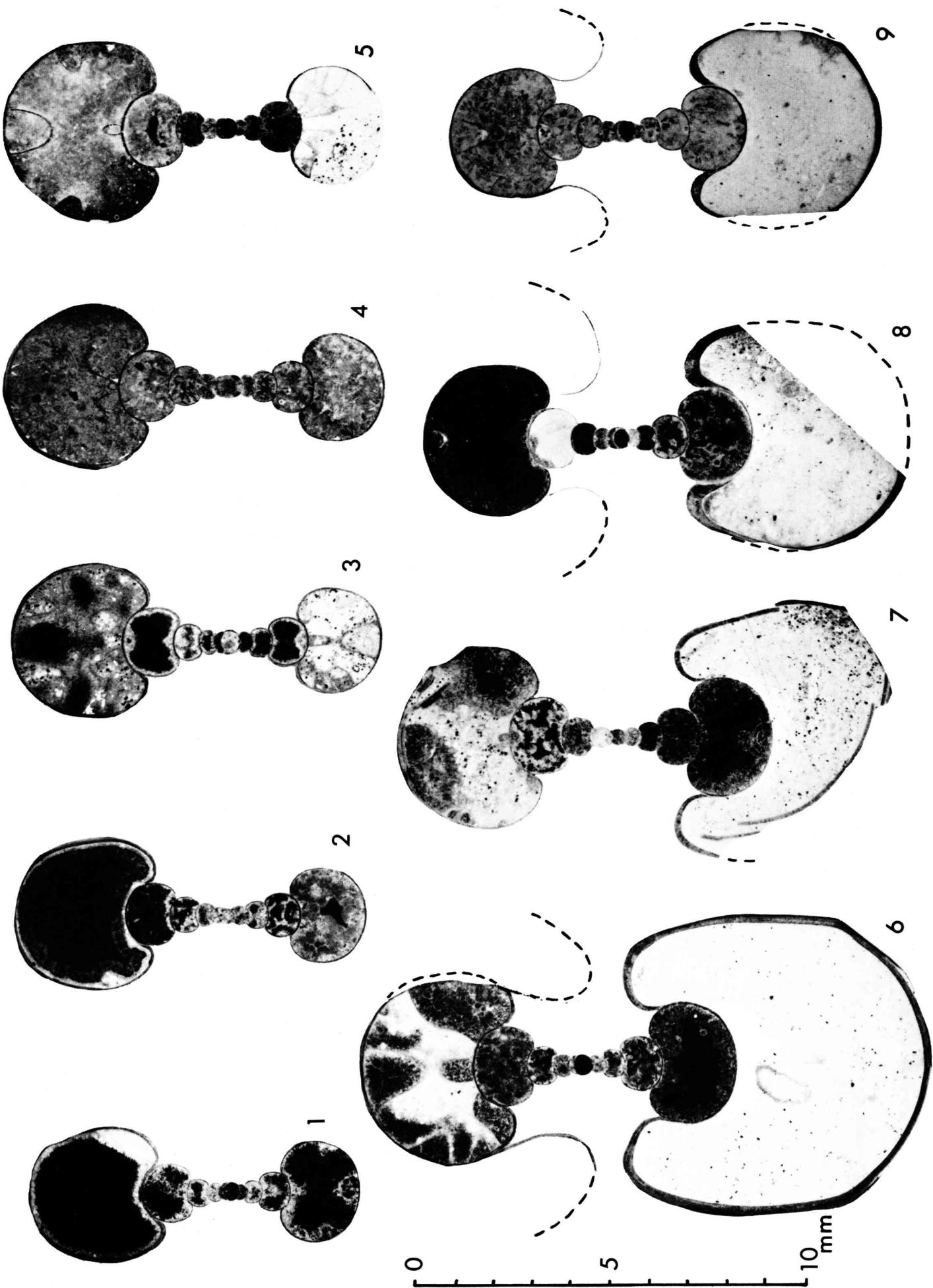

K. TANABE: Functional Evolution of Otoscaphites and Scaphites 
p. 249, pl. 24, figs. 6a-e.

1965. Scaphites planus YABE: Verechagin et al., A Field Atlas of the Cretaceous Fauna from Northeast Soviet Socialist Republics, p. 41-42, pl. 33, figs. 3a, b.

Remarks.-As MATSUmoto (1959b) pointed out, the present species closely resembles $S$. condoni ANDERSON $(1902,1958)$ from the Upper Cretaceous of Oregon, in the surface ornament and inflation of adult shells. But the adult suture of $S$. condoni is somewhat simpler than that of $S$. planus. At present I cannot decide whether the small difference between these two species is merely intraspecific variation or not.

YABE's (1910) var. gigas may attributed to the strongly ribbed type of the present species.

Geographic distribution.-The present species occurs abundantly in Hokkaido and south Sakahlin. It is also known from near the Bay of Penzhina, northeast Siberia (VERECHAGIN et al., 1965).

\section{Summary}

Otoscaphites puerculus (JIMBO) and Scaphites planus (YABE) are the dominant ammonites in the silty mudstone facies of the Turonian of Hokkaido and south Sakahlin. In this study, I have considered the functional evolution of the two species on the basis of biometric and hydrostatic examinations of numerous specimens from the Naibuchi area of south Sakhalin, and the Saku, Obira and Oyubari areas of Hokkaido. The results of this study are summarized as follows.

1) The results of relative growth analysis indicate that both species evolved gradually in the direction of a buoyancy excess.

2) Judging from such indirect data as the results of approximate calculation of shell density and the analyses of relative growth and mode of occurrence, O. puerculus may have changed its mode of life in the adult stage from benthic to planktic with time. The results of buoyancy calculations also suggest a benthic mode of life in the adult stage of $S$. planus from the Lower to the lower Middle Turonian. During the normally coiled stage, the two species might have been maintained a nektoplanktic mode of life throughout Turonian because of their slightly negative allometric or isometric growth of shell thickness as well as many normally coiled ammonites.

3) A high stability in the adult stage of the two species may indicate that they could not swim so quickly as many normally coiled ammonoids.

4) Both species have a siphuncular strength smaller than that of Nautilus macromphalus SOWERBY; accordingly, their depth range was probably less than that of $N$. macromphalus (0-ca. $300 \mathrm{~m}$, DentoN and GILPIN-Brown, 1973).

5) An intimate relationship is observed between the increase in suture complexity and the thinning of septal and ventral wall thickness in the two species. This evidence may support SEILACHER's (1975) interpretation that the suture evolution in ammonoids has reduced the unsupported areas in the phragmocone wall to a minimum, allowing further thinning of the outer wall. 
6) The identity of geographic and stratigraphic distribution, mode of occurrence, evolutionary patterns of several characters and growth patterns in the early to middle growth-stages may suggest that the two nominal species are sexual dimorphs.

\section{References Cited}

Anderson, F. M. (1902): Cretaceous deposits of the Pacific Coast. Proc. Calif. Acad. Sci., [3], 2, (1), 1-154, pls. 1-12.

(1958) : Upper Cretaceous of Pacific Coast. Geol. Soc. Amer., Special Papers, (16), 339 p., 84 pls.

BIDDER, A. M. (1962) : Use of tentacles, swimming and buoyancy control in the Pearly Nautilus. Nature, 196, (4853), 451-454.

Calloman, J. H. (1963) : Sexual dimorphism in Jurassic ammonites. Leicester Lit. Phil. Soc. Trans., 57, 21-56.

Cobban, W. A. (1951): Scaphitoid cephalopods of the Colorado Group. U.S. Geol. Surv. Prof. Paper, 239, 42 p., 21 pls.

- (1969): The Late Cretaceous ammonites Scaphites leei REESIDE and Scaphites hippocrepis (DEKAY) in the Western Interior of the United States. Ibid., 619, 27 p., 5 pls.

Collins, D. H. and Minton, P. (1967): Siphuncular tube of Nautilus. Nature, 216, (5118), 916-917.

Denton, E. F. and Gilpin-Brown, J. B. (1961a): The buoyancy of the cuttlefish Sepia officinalis (L.). Jour. Mar. Biol. Assoc., U. K., 41, 319-342.

and (1961): The distribution of gas and liquid within the cuttlebone. Ibid., 41, 365-381.

and - (1966): On the buoyancy of the Pearly Nautilus. Ibid., 46, 723-759. and (1971): Further observation on the buoyancy of Spirula. Ibid., 51, 363-373.

and - (1973): Floatation mechanisms in modern and fossil cephalopods In RUSSel, F. S. and YoNGE, M. eds., Advances in Marine Biology, 11, 197-268, Academic Press, London.

- - - and HowARTh, J. V. (1967): On the buoyancy of Spirula spirula. Jour. Mar. Biol. Ass., U.K., 47, 181-191.

Erben, H. K., Flajs, G. and Siehl, A. (1969): Die Frühontogenetische Entwicklung der Schalenstruktur ectocochliater Cephalopoden. Palaeontolographica, [A], 132, 1-54, pls. 1-15.

- and REID, E. H. (1971) : Ultrastructure of shell, origin of conellae and siphuncular membrances in an ammonite. Biomineralization, 3, 22-31.

HAARLÄNDER, W. (1952): Die Spirale der Ammonoidea. Geol. Blätter für Nordost Bayern, U.S. W., 2, (1), 1-15, pl. 1.

HAMAdA, T. (1964): Notes on the drifted Nautilus in Thailand. Contributions to the Geology and Palaeontology of Southeast Asia, 21. Sci. Papers Coll. Gen. Educ., Univ. Tokyo, 14, (2), 255-278, pls. 1-5.

(1965) : Post-mortem drift of Nautilus (in Japanese). Venus (Jour. Malacol. Soc. Japan), 24, (3), 181-198, pl. 20.

Haven, N. (1972) : The ecology and behavior of Nautilus pompilius in the philippines. Veliger, 15, (2), 75-80.

Heptonstall, W. B. (1970): Buoyancy control in ammonoids. Lethaia, 3, (4), 317328.

Hirano, H., Tanabe, K. and Matsumoto, T. (1977) : Mid-Cretaceous stratigraphy of the Oyubari area, central Hokkaido In Mid-Cretaceous Events, Hokkaido Sympo- 
sium, 1976. Palaeont. Soc. Japan., Special Papers, (21), 1-10.

HouŠ, V. (1965): Sexual dimorphism and the system of Jurassic and Cretaceous Ammonoidea (Preliminary note). Gasopis Musea Narodniho (Prague), 134, (1), $33-35$.

Huxley, J. S. (1932) : Problems of Relative Growth. 276 p., Dial Press, New York.

Jiмво, K. (1894) : Beiträge zur Kenntnis der Fauna der Kerideformation von Hokkaido. Palaeont. Abh., Neue Folge, 2, (3), 47 p., 9 pls.

Kermack, K. A. and Haldane, J. B. S. (1950): Organic correlation and allometry. Biometrika, 37, 30-41.

KullmanN, J. and WiedmanN, J. (1970): Significance of sutures in phylogeny of Ammonoidea. Univ. Kansas Paleont. Contr., (47), 32 p.

Mahalonobis, J. C., Majumdar, D. N. and RaO, C. R. (1949) : Anthropometric survey of the United Provinces, 1941: a statistical study. Sankhyā, 9, 89-324.

Makowski, H. (1962): Problem of sexual dimorphism in ammonites. Palaeontologia Polonica, (12), 92 p., 20 pls.

Matsumoto, T. (1942) : Fundamentals in the Cretaceous stratigraphy of Japan. Pt. 1. Mem. Fac. Sci., Kyushu Imp. Univ., [D], 1, (3), 133-380, pls. 5-20.

(1943) : Fundamentals in the Cretaceous stratigraphy of Japan. Pts. 2-3. Ibid., 2, (1), 97-237.

(1959a): Zonation of the Upper Cretaceous in Japan. Mem. Fac. Sci., Kyushu Univ., [D], Geol., 9, (2), 55-93, pls. 1-2.

(1959b) : Upper Cretaceous ammonites of California. Pt. 2. Ibid., Special vol. 1, $172 \mathrm{p.}, 41 \mathrm{pls}$.

(1963) : A survey of the fossils from Japan illustrated in classical monograph (Primarily a nomenclatorial revision). Pt. 10. Palaeont. Soc. Japan, 25th Annivers. vol., 41-48, pls. 60-68.

(1967) : Cretaceous Period In Historical Geology. Pt. 2 (in Japanese). 408477, Asakura-shoten, Tokyo.

and OKADA, H. (1973): Saku formation of the Yezo geosyncline (in Japanese with English abstract). Sci. Rep., Dept., Geol. Kyushu Univ., 11, (2), 275-309. , Muramoto, T. and Inoma, A. (1972) : Two small desmoceratid ammonites from Hokkaido (Studies of the Cretaceous ammonites from Hokkaido and Saghalien 24). Trans. Proc. Palaeont. Soc. Japan. N.S., (87), 377-394, pl. 47.

, OKada, H., Hirano, H. and TANABE, K. (1977): Mid-Cretaceous biostratigraphic succession in Hokkoido In Reyment, R. A. ed., IGCP. Project, MidCretaceous Events, Report. 1st Intern. Conf. Ann. Muséum d'Hist. Nat. Nice, 30-1 30-11.

MaYr, E. (1970): Populations, Species and Evolution. 453 p., Harvard Univ. Press, Cambridge.

- Linsley, E. G. and Usinger, R. L. (1953) : Methods and Principles of Systematic Zoology. 336 p., McGraw-Hill, New York.

Moseley, H. (1838): On the geometrical forms of turbinated and discoid shells. Phil. Trans. Roy Soc. London in 1838, 351-370.

MUtver, H. (1967): On the microscopic shell structure in some Jurassic ammonoids. Neues Jb. Geol. Paläont., 129, 157-166.

(1975): The mode of life in ammonoids. Paläont. Z., 49, (3), 196-202.

and REYMENT, R. A. (1973) : Buoyancy control and siphuncle function in ammonoids. Palaeontology, 16, (3), 623-636.

ОватA, I. (1959) : Croissance relative sur quelques Espéces des Desmoceratidae. Mem. Fac. Sci., Kyushu Univ., [D], Geol., 9, (1), 33-45, pls. 3-5. (1960): Spirale de quelques ammonites. Ibid., 9, (1), 151-163, pl. 15.

Palframan, D. F. B. (1969): Taxonomy of sexual dimorphism in ammonites: morphologenetic evidence in Hecticoceras brightii (Pratt) In WestermanN, G. E. G. 
ed., Sexual Dimorphism in Fossil Metazoa and Tamonomic Implications. 126-154, pls. 6-8, Internat. Union Geol. Sci., [A], (1).

RAO, C. R. (1952): Advanced Statistical Methods in Biometric Research. 390 p., John Wiley and Sons, New York.

RAUP, D. M. (1966): Geometric analysis of shell coiling: general problems. Jour. Paleont., 40, (5), 1178-1190.

(1967) : Geometric analysis of shell coiling: coiling in ammonoid shells. Ibid., 41, (1), 43-65.

(1972): Approaches to morphologic analysis In Schopf, T. J. M. ed., Models in Paleobiology, 28-44. Freeman, San Francisco.

(1973): Depth inferences from vertically imbedded cephalopods. Lethaia, 6, (3), 217-225.

and Michelson, A. (1965): Theoretical morphology of the coiled shell. Science, $147,1294-1295$.

and Takahashi, T. (1966): Experiments on strength of cephalopod shells.

Bull. Geol. Soc. Amer., Program for 1966 Annual Meetings, 172-173.

and Chamberlain, J. A. Jr. (1967) : Equations for volume and centre of gravity ammonoid shells. Jour. Paleont., 41, (3), 556-574.

REYMENT, R. A. (1958) : Factors in the distribution of fossil cephalopods. Stockholm Contr. Geol., 1, (6), 98-185, pls. 1-7.

(1973) : Factors in the distribution of fossil cephalopods. Pt. 3. Experiments with exact models of certain shell types. Bull. Geol. Inst. Univ. Uppsala, N.S., 14, (2), 7-41.

and SANDERBERG, P. (1963): Biometric study of Barremites subdifficilis (KARAKASCH). Palaeontology, 6, (4), 727-730.

Roman, F. and Mazeran, P. (1920): Monographie paléontologique de la faune turonienne du bassin d'Uchaux et de ses dépendances. Mus. Hist. Nat. Lyon Archieves, 12, (2), 137 p., 11 pls.

Schindewolf, O. H. (1960): Studien zur Stammesgeschichte der Ammoniten. Akad. Wiss. Lit. Mainz. Math.-Nat. Kl., (10), 109 p., 2 pls.

SEAL, H. L. (1964) : Multivariate Statistical Analysis for Biologists. 209 p., Spottiswoode, Ballantyne Co., London.

SEILACHER, A. (1970): Arbeitskonzept zur Konstruktions-Morphologie. Lethaia, 3, (4), 393-396.

(1975): Mechanische Simulation und funktionelle Evolution des AmmonitenSeptums. (Konstruktionsmorphologie, Nr. 34). Paläont. Z., 49, (3), 268-286.

TANABE, K. (1975): Functional morphology of Otoscaphites puerculus (JiMBo), an Upper Cretaceous ammonite. Trans. Proc. Palaeont. Soc. Japan, N.S., (99), 109132, pls. 10-11.

(1977): Mid-Cretaceous scaphitid ammonites from Hokkaido In Mid-Cretaceous Events, Hokkaido Symposium, 1976. Palaeont. Soc. Japan, Special Papers, (21), 11-22, pl. 1 .

, Hirano, H., Matsumoto, T. and Miyata, Y. (1977): Stratigraphy of the Upper Cretaceous deposits in the Obira area, northwestern Hokkaido (in Japanese with English abstract). Sci. Rep., Dept. Geol. Kyushu Univ., 12, (3), 181202.

Tномpson, D'arcy, W. (1917) : On Growth and Form. 1116 p., Cambridge Univ. Press, London.

TORIYAMA, R., SATo, T. and HAMAdA, T. (1965) : Nautilus pompilius drift on the west coast of Thailand. Contributions to the Geology and Palaeontology of Southeast Asia 20. Japan Jour. Geol. Geogr., 36, (2-4), 149-161, pl. 3.

TRUEman, A. E. (1941): The ammonite body-chamber, with special reference to the buoyancy and mode of life of the living ammonites. Quart. Jour. Geol. Soc. London, 96, (4), 339-383. 
Verechagin, V. N., Kinasov, V. P., Parakechov, K. V. and Terexova, G. P. (1965) : A Field Atlas of the Cretaceous Fauna from Northeast Soviet Socialist Republics (in Russian). 66 p., 74 pls., Nat. Industrial Geol. Com. U. S. S. R. Magadan.

WAdDINGTON, C. H. (1929): Notes on graphical methods of recording the dimension of ammonites. Geol. Mag., 66, 180-186.

Westermann, G. E. G. (1964): Sexual dimorphismus bei Ammonoideen und seine Bedeutung für die Taxionomie der Otoitidae. Palaeontographica, [A], 124, 3373 , pls. $6-9$.

- (1971) : Form, structure and function of shell and siphuncle in coiled Mesozoic ammonites. Life Sci. Contr. Royal Ontario Mus., (78), $39 \mathrm{p}$. (1975) : Model for origin, function and fabrication of fluted cephalopod septa. Paläont. Z., 49, (3), 235-253.

Wiedmann, J. (1965): Origin, limits and systematic position of Scaphites. Palaeontology, 8, (3), 397-453, pls. 53-60.

(1969): The heteromorphs and ammonoid extinction. Biol. Rev., 44, 563-602, pls. 1-3.

Wright, C. W. (1953) : Notes on Cretaceous ammonites. 1. Scaphitidae. Ann. Mag. Nat. Hist., [12], 6, 473-476.

YABE, H. (1910): Die Scaphiten aus der Oberkreide von Hokkaido. Beitr. Paläont. Geol. Oesterr.-Ungarns u. des Orients, 23, 159-174, pl. 15. 